\title{
AS "GEOMETRIAS" DO TRÁFICO: O COMÉRCIO METROPOLITANO E 0 TRÁFICO DE ESCRAVOS EM ANGOLA (1796-1807)
}

\author{
Maximiliano M. Menz \\ Universidade Federal de São Paulo, jovem pesquisador da Fundação \\ de Amparo à Pesquisa do Estado de São Paulo
}

\begin{abstract}
Resumo
O artigo apresenta uma análise comparada dos registros alfandegários de Portugal e Angola entre 1796 e 1807 e demonstra que a metrópole portuguesa era responsável por mais da metade do financiamento do tráfico em Angola neste período. Além disso, discute aspectos relacionados ao financiamento do resgate e do transporte de escravos, reavaliando a participação dos mercadores coloniais no negócio.
\end{abstract}

Palavras-chave

tráfico triangular $\bullet$ financiamento $\bullet$ transporte $\bullet$ escravos.

\section{Contato:}

Universidade Federal de São Paulo

Escola de Filosofia, Letras e Ciências Humanas

Estrada do Caminho Velho, 333 - Bairro dos Pimentas

07252-312 - Guarulhos - SP

E-mail:mmenz@unifesp.br

\footnotetext{
* Pesquisa realizada com apoio da Fapesp. O autor agradece a Gustavo Acioli Lopes e Natalia Tamone pela indicação de alguns importantes documentos para a elaboração do artigo, a Guilherme Conigiero pela elaboração dos mapas e a Diego Cambraia Martins por ter auxiliado na organização das planilhas.
} 


\title{
THE "GEOMETRIES" OF TRADE: METROPOLITAN COMMERCE AND SLAVE TRADE IN ANGOLA (1796-1807)*
}

\author{
Maximiliano M. Menz \\ Universidade Federal de São Paulo, scholar-holder of \\ Fundação de Amparo à Pesquisa do Estado de São Paulo
}

\begin{abstract}
The article presents a comparative analysis of customs records of Portugal and Angola between 1796 and 1807 and shows that the metropolis was responsible for more than half of the financing of slave trade in Angola during this period. In addition, it discusses issues related to the financing of ranson and transportation of slaves, reviewing the participation of colonial merchants in the business.
\end{abstract}

Keywords

Triangular trade $\bullet$ financing $\bullet$ transport $\bullet$ slaves.

\section{Contact:}

Universidade Federal de São Paulo

Escola de Filosofia, Letras e Ciências Humanas

Estrada do Caminho Velho, 333 - Bairro dos Pimentas

07252-312 - Guarulhos - SP

E-mail: mmenz@unifesp.br

* Research with support of Fapesp. The autor thanks Gustavo Acioli Lopes and Natalia Tamone for the indication of some importante documents for the preparation of the article, Guilherme Conigiero for the preparation os maps and Diego Cambraia Martins for helping in the organization of spreadsheets. 


\section{Maximiliano Mac MENZ. As "geometrias" do tráfico.}

Nos últimos vinte anos, consolidou-se um verdadeiro consenso historiográfico em torno da ideia de que o tráfico de escravos era controlado pelos mercadores residentes no Brasil, ao menos desde o século XVIII. O consenso foi gerado a partir da publicação dos trabalhos de Manolo Florentino e Luiz Felipe Alencastro e vem sendo reproduzido por autores como Antonio Jucá Sampaio, Roquinaldo Ferreira e Alexandre Ribeiro.

Existem, é claro, nuances nestas interpretações e diferenças no que diz respeito ao recorte geográfico e temporal que a tese abrangeria: Manolo Florentino afirma que os mercadores "cariocas" dominariam o tráfico de escravos desde o início do século XVIII, tese baseada na extrapolação de seus dados pós 1808 e em alguns testemunhos qualitativos. ${ }^{1}$

Já para Luiz Felipe Alencastro, a presença "brasílica" teria sido estabelecida desde a segunda metade do século XVII, depois das guerras luso-holandesas, com o estabelecimento de governadores brasílicos em Angola. A preeminência do Rio de Janeiro só teria se estabelecido a partir do século XVIII, graças à utilização da jeribita no tráfico de escravos. Esta última afirmação assenta-se sobre um cálculo de José Curto, segundo o qual as exportações de jeribita pagariam 25\% dos escravos adquiridos pela América Portuguesa no mesmo século. Acrescenta a isto o estudo quantitativo de Corcino Santos, onde consta que apenas $15 \%$ dos navios negreiros aportados em Luanda no século XVIII haviam partido de Lisboa. ${ }^{2}$

Jucá de Sampaio, por sua vez, manifestou dúvidas em relação ao predomínio "carioca" no início do século, mas não concedeu aos arcaicos mercadores metropolitanos uma participação no tráfico, preferindo sugerir a ação de contrabandistas estrangeiros em Angola para criticar a "miragem do exclusivo metropolitano". Roquinaldo Ferreira considerou que a cachaça e os têxteis asiáticos teriam sido a chave para o controle colonial do resgate em Benguela e Angola, demarcando apenas uma mudança no centro de gravidade americano, da Bahia para o Rio de Janeiro, durante o século XVIII. Finalmente, Alexandre Ribeiro reproduziu a tese de Manolo Florentino para a Bahia, sem aprofundar este debate específico, tendo em vista que o escopo de sua pesquisa era principalmente quantificar as importações de escravos. ${ }^{3}$

FLORENTINO, Manolo. Em Costas Negras. São Paulo: Cia das Letras, 1997, p. 177-184.

2 ALENCASTRO, Luiz Felipe de. O Trato dos Viventes: formação do Brasil no Atlântico Sul. São Paulo: Companhia das Letras, 2000, p. 248-251, 28-29, 323-324.

3 Cf. SAMPAIO, Antonio C. Na Encruzilhada do Império. Hierarquias sociais e conjunturas econômicas no Rio de Janeiro. Rio de Janeiro: Arquivo Nacional, 2001, p. 148-184. FERREIRA, Roquinaldo. Transforming Atlantic Slaving: Trade, warfare and territorial control in Angola, 
Apesar dos méritos desta historiografia, é curioso notar que o consenso constituiu-se sobre frágeis evidências quantitativas. Os números de Alencastro e as extrapolações de Florentino são pouco consistentes, enquanto que Ferreira e Sampaio não apresentam nenhuma evidência serial, mas apenas testemunhos indiretos, passíveis de diferentes interpretações, e algumas negociações isoladas, baseadas em micro biografias de traficantes. ${ }^{4}$

O consenso também choca-se com a interpretação dos historiadores norteamericanos Herbert Klein e Joseph Miller. Klein, ainda nos anos 70, notava a participação dos mercadores residentes no Brasil no transporte de escravos, mas realçava o papel dos capitalistas de Lisboa no financiamento. Já Miller, a maior autoridade sobre o tráfico em Angola, propõe uma visão bastante diferente das conjunturas do tráfico: de acordo com ele, durante o século XVII, o tráfico era controlado pelos governadores de Angola, demarcando a simbiose entre os conflitos militares no sertão e a captura dos cativos. A repressão da monarquia à participação dos governadores no comércio e a relativa desaceleração nos conflitos entre os colonizadores e os reinos africanos do interior deram lugar a um resgate de escravos regulado mais pelo comércio, operado pelos mercadores de Luanda, do que pela captura direta. A partir dos anos de 1720-1730, portanto, o financiamento do comércio de escravos passou a ser dominado pelos homens de negócio de Lisboa que se sucediam no contrato do estanco do marfim e da cobrança de impostos sobre a exportação de escravos.

Ainda segundo J. Miller, esta situação teria mudado na década de 1780 quando os mercadores do Brasil, que até então se dedicavam ao comércio de cachaça e ao transporte de escravos, abocanharam uma maior parte do negócio graças à retração dos capitais lisboetas, que sucedeu à crise do ouro, e ao acesso de mercadorias europeias de resgate fornecidas por contrabandistas ingleses. No entanto, é notável que o professor norte-americano, apesar conhecer de modo bastante profundo as fontes originais e os registros da alfândega de Luanda, tenha apresentado poucos dados quantitativos em sua obra máxima, Way of Death; apenas em artigos anteriores foi publicada parte destes números. ${ }^{5}$

1650-1800. PhD Dissertation, University of California, 2003. RIBEIRO, Alexandre Vieira. O tráfico atlântico de escravos e a praça mercantil de Salvador. Dissertação de Mestrado, UFRJ, 2005.

4 Cf. ainda LOPES, Gustavo Acioli; MENZ, Maximiliano M. Resgate e Mercadorias: Uma análise comparada do tráfico luso-brasileiro em Angola e na Costa da Mina (século XVIII). Afro-Ásia, $\mathrm{n}^{\mathrm{o}} 37,2008$.

5 Cf. KLEIN, Herbert. The portuguese slave trade from Angola in 18th century. In: Idem, The Middle Passage. Princeton: Princeton University Press, 1978, p. 23-50. MILLER, Joseph. Way of Death: Merchant Capitalism and the Angolan Slave Trade, 1730-1830. Winscosin: Universisty of 


\section{Maximiliano Mac MENZ. As "geometrias" do tráfico.}

Além dos livros pioneiros de Herbert Klein e Joseph Miller, alguns poucos trabalhos mais recentes têm contribuído para problematizar o consenso. Daniel Domingues da Silva demonstrou que o tráfico para o Maranhão na segunda metade do século XVIII era controlado pelos grandes capitalistas da praça de Lisboa, ligados às Companhias Pombalinas. O estudo não questiona as teses dominantes; pelo contrário, procura argumentar que depois de 1788 os negociantes coloniais dominariam o tráfico para aquela região. Mesmo assim, é um trabalho importante, pois sugere outras vias de interpretação a respeito do comércio de escravos. ${ }^{6}$

Neste sentido, é de fundamental importância a tese de Gustavo Acioli Lopes Negócio da Costa da Mina, pois questiona a interpretação tradicional sobre o tráfico na Costa da Mina, mostrando que, para além do tabaco, os mercadores da Bahia e de Pernambuco carregavam também ouro, trocado por têxteis nas feitorias europeias da Costa da África. Ademais, demonstra com fontes portuguesas que embarcações metropolitanas também resgatavam escravos na África Ocidental durante a primeira metade do século XVIII. Vale mencionar ainda o artigo que escrevi com Gustavo Acioli Lopes no qual apresentamos elementos de prova que permitem relativizar a interpretação canônica sobre o tráfico na Costa da Mina e Angola?.

Dadas as frágeis evidências seriais apresentadas originalmente por Florentino e Alencastro, é preciso perguntar os fundamentos do consenso. Arrisco-me a sugerir alguns: em primeiro lugar, a obra de Joseph Miller nunca foi traduzida ao grande público brasileiro e a ausência de dados quantitativos em seu livro

Winscosin Press, 1988. MILLER, Joseph. Imports at Luanda, Angola 1785-1823. In: PASCH, G.; JONES, A. Figuring African Trade. Berlin: Reimer, 1986. MILLER, Joseph. Slave Prices in the Portuguese Southern Atlantic, 1600-1830. In: LOVEJOY, Paul (Ed.). Africans in Bondage. Studies in slavery and slave trade. Winscosin: African Studies Program, University of Winscosin, 1986.

6 SILVA, Daniel Domingues da. The Atlantic Slave Trade to Maranhão, 1680-1846. Volume, Routes and Organization. Slavery \& Abolition, v. 29, n. 4, 2008, p. 477-501. O argumento sobre o domínio dos mercadores das praças brasileiras após 1788 é negativo: mesmo notando um domínio avassalador das rotas triangulares, ainda depois de 1788, o autor ressalta que apenas três dos proprietários de embarcações podem ser encontrados na lista dos grandes capitalistas de Lisboa organizada por Jorge Pedreira; conclui então que "provavelmente mercadores residentes em São Luís ou outros portos brasileiros aumentaram o controle sobre o carregamento de escravos para o Maranhão". (p. 489, trad. minha). No entanto, a ausência destes proprietários na lista de Pedreira pode significar simplesmente uma mudança no grupo mercantil lisboeta, com a saída dos grandes capitalistas e a entrada de pequenos comerciantes. Vale dizer, aliás, que estas deduções sobre os proprietários de embarcações são sujeitas a dúvidas (ver nota 22).

7 LOPES, Gustavo Acioli. Negócio da Costa da Mina e comércio atlântico - tabaco, açúcar, ouro e tráfico de escravos: Pernambuco (1654-1760). Tese de Doutorado, USP, 2008; LOPES, Gustavo Acioli; MENZ, Maximiliano M. Resgate e Mercadorias:..., op. cit. 
que, de modo explícito, afrontassem a tese dominante pode ter estimulado o seu esquecimento.

Além disso, as tradições historiográficas do final da década de 80 podem ter facilitado a aceitação do consenso. A interpretação do domínio do tráfico por parte dos mercadores coloniais encontra raízes nas obras de Affonso de Taunay, Pierre Verger e Mauricio Goulart, que apontavam para a existência de um comércio direto entre o Brasil e a África, destacando o comércio luso-brasileiro em relação às demais carreiras negreiras supostamente triangulares. A ideia combinava-se de modo harmônico com a tese de um mercado interno colonial ou então com a inversão de polos entre metrópole e colônia que configuraria a crise do Antigo Sistema Colonial. Finalmente, o domínio brasileiro sobre o tráfico iluminaria a importância deste negócio durante o Primeiro Reinado e explicaria, em grande parte, os debates políticos em torno do tema no século XIX.

Por último, apesar de o consenso não ser baseado em dados seriais, foi a partir desta tese que foram produzidos diversos estudos quantitativos que, aparentemente, confirmaram a ideia do domínio do "capital mercantil residente" sobre o tráfico. Destaco o material do Transatlantic Slave Trade Database, constituído a partir do registro massivo de viagens negreiras para o qual contribuíram os estudiosos brasileiros. Esta base de dados demonstra que 91\% dos escravos embarcados em Luanda entre 1701 e 1807 teriam sido transportados por navios originados em portos brasileiros. ${ }^{8}$

O presente artigo, porém, questiona o consenso historiográfico: através da análise comparada dos registros alfandegários de Portugal e Angola entre 1796 e 1807, procura-se demonstrar que a metrópole portuguesa era responsável por mais da metade do financiamento do tráfico em Angola, fornecendo a maior parte das mercadorias utilizadas no resgate neste período.

A preocupação em quantificar a participação metropolitana no tráfico e a crítica à corrente historiográfica dominante pode parecer ociosa e até mesmo anacrônica atualmente. Afinal, como mostram os trabalhos mais atuais a respeito das comunidades mercantis no Império português, o estágio no Brasil costumava

\footnotetext{
Variáveis utilizadas para a pesquisa na base de dados: principal local de desembarque (Brasil), local onde a viagem começou (Brasil e/ou Portugal); bandeira da embarcação (portuguesa); principal ponto de compra dos escravos (Luanda). O total de viagens iniciadas em Portugal foi de 129. O total de viagens iniciadas no Brasil foi de 1.722. (http://www.slavevoyages.org/; consultado em 07/01/2010). Note-se que os dados do database não são completos: em meu levantamento nos arquivos de Lisboa levantei 205 passaportes de embarcações reinóis com destino a Angola entre 1757 e 1807 , ver as fontes da tabela 9 , no apêndice.
} 
ser passageiro para os mercadores das praças brasileiras, fortemente articulados com os homens de negócio de Lisboa; trocando em miúdos, o capital mercantil colonial não era residente e nem autônomo num sentido estrito. ${ }^{9}$ Pretendo argumentar que o problema da participação metropolitana no tráfico deve ser colocado de modo diferente, portanto. Ao invés de buscarmos hierarquias pessoais nas trajetórias de homens de negócio, é preciso reconstituir as funções econômicas de cada região do Império articuladas pelo comércio de escravos, de modo a revelar as hierarquias espaciais, definidas pelos tipos de mercadorias utilizadas para o resgate e pelos fluxos financeiros do negócio.

Para tanto, apresentarei cálculos a respeito da participação relativa das mercadorias metropolitanas no comércio angolano. Em seguida, analisarei as principais mercadorias utilizadas pelos traficantes lisboetas. Na terceira parte do artigo reconstituirei algumas das rotas dos navios metropolitanos, retomando a tese do tráfico triangular; tal análise, no entanto, deve ser cotejada com os dados das balanças comerciais e dos mapas de exportação e importação que permitem certas aproximações a uma contabilidade do comércio do Atlântico Português. A última parte será uma discussão, ainda que não exaustiva, a respeito do papel das embarcações "brasílicas" no tráfico. Na conclusão, pretendo sugerir quais as consequências historiográficas que podem ser retiradas a partir deste estudo e novas hipóteses para trabalhos futuros.

As fontes deste artigo são, em primeiro lugar, as balanças de comércio portuguesas, no intervalo entre 1796 e 1807. Como já é bem sabido, estas balanças de comércio não apenas demonstravam os valores das exportações e importações portuguesas, como também discriminavam as quantidades e os tipos de mercadorias exportadas e importadas por Portugal, tornando-se, portanto, uma fonte obrigatória para o estudo da economia portuguesa nessa passagem de século. Apesar de as fontes terem sido aproveitadas numa grande quantidade de textos a respeito do comércio de Portugal com o Brasil ou com a Europa, praticamente foram ignoradas nos trabalhos a respeito do tráfico de escravos.

As razões para o subaproveitamento destas fontes são muitas: em primeiro lugar, e por motivos óbvios, o tráfico de escravos propriamente dito não era registrado pelas balanças portuguesas. Além disso, como demonstrarei ao longo do

9 Cf. PEDREIRA, Jorge. Brasil, fronteira de Portugal. Negócio, emigração e mobilidade social (séculos XVII e XVIII). In: CUNHA, Mafalda (Coord.). Do Brasil à Metrópole, efeitos sociais (séculos XVII-XVIII). Anais da Universidade de Évora, n. 8 e 9, 1998/1999, p. 47-72; e PESAVENTO, Fábio. Um pouco antes da Corte: a economia do Rio de Janeiro na segunda metade do setecentos. Tese de Doutorado, UFF, 2009. 
texto, o próprio comércio português na África no final do século XVIII e início do XIX era insignificante frente ao comércio com o Brasil. Finalmente, foi só nos últimos 20 anos que os temas relacionados com o comércio de escravos no Brasil ganharam relevância na historiografia e pelas já referidas teses que procuraram realçar os vínculos diretos entre o Brasil e as possessões portuguesas na África. Supôs-se implicitamente, portanto, que as balanças teriam pouco o que dizer a respeito do tráfico de escravos.

Além das balanças de comércio existem registros alfandegários do porto de Luanda em séries relativamente completas ao menos desde 1785. Estas séries são o resultado do esforço de reorganização Imperial empreendido pelos secretários de Marinha e Ultramar ao menos desde Martinho de Mello e Castro; o centro lisboeta procurou estimular a produção de dados demográficos, econômicos e naturais que permitissem conhecer as condições dos domínios portugueses do Ultramar. Ao contrário das balanças, estes números foram bem explorados pelos estudos de J. Miller e J. Curto sobre o tráfico e, sendo assim, aproveitarei os dados publicados por estes autores para comparar com os dados copilados nos arquivos portugueses. ${ }^{10}$

Completam as fontes quantitativas os mapas de exportação e importação dos portos da Bahia e do Rio de Janeiro. A série baiana é completa (1797-1807) e fiável, enquanto que os mapas do Rio fornecem alguns dados úteis, mas, como será discutido no momento apropriado, não permitem calcular déficits e superávits.

Para redigir o artigo consultei ainda alguns documentos qualitativos que pude acessar em arquivos brasileiros e portugueses: destaco as correspondências dos governadores de Angola, D. Francisco Inocencio Coutinho e D. Miguel Antonio de Mello, que revelam as particularidades do negócio.

\section{Estimativa da participação metropolitana no tráfico (1796-1807)}

Qual era a participação metropolitana no tráfico? Para responder a esta pergunta é preciso superar as limitações das fontes, pois os registros de Luanda não apresentam o porto de origem das cargas, mas sim os lugares de produção das diferentes mercadorias. Assim, estas estão divididas por quatro classes de origem:

\footnotetext{
${ }^{10}$ MILLER, Joseph. Imports at Luanda..., op. cit.; MILLER, Joseph, Way of Death:..., op. cit.; CURTO, José C. Álcool e Escravos. O comércio luso-brasileiro do álcool em Mpinda, Luanda e Benguela durante o tráfico atlântico de escravos (c. 1480-1830) e o seu impacto nas sociedades da África Central e Ocidental. Trad. Márcia Lameirinhas, Lisboa: Vulgata, 2002.
} 


\section{Maximiliano Mac MENZ. As "geometrias" do tráfico.}

Fazendas e gêneros da Cultura e Indústria de Portugal que tiveram despacho na alfândega desta cidade, Fazendas e gêneros da Cultura e Indústria da América Portuguesa, Fazendas e gêneros da cultura e indústria da Ásia, Fazendas e gêneros da cultura e indústria das Nações da Europa que Sua Majestade Permite entrada nos seus domínios. ${ }^{11}$

Portanto, para estimar a participação relativa dos capitais lisboetas é necessário cruzar os registros da alfândega de Luanda com as balanças comerciais portuguesas. Existem dois métodos de cruzar estes registros: o primeiro é calcular a parte que as exportações desde Portugal ocuparam nas importações gerais registradas em Luanda, ao menos quando estes registros existem. O segundo método é calcular o "poder de compra" das exportações portuguesas frente ao valor dos escravos exportados a partir de Luanda.

Os dois métodos possuem inconveniências; no primeiro caso, as balanças portuguesas apresentam preços evidentemente inferiores aos praticados no mercado angolano, pois ao preço no momento da exportação seria necessário incluir os custos de transação. Mas as diferenças entre pesos, medidas, qualidades e classificações nos dois registros não permitem um cálculo seguro a respeito desta variação. Apenas no caso das pipas de vinho foi possível fazer uma comparação segura e os preços de Angola são entre $26 \%$ e $81 \%$ mais caros do que em Portugal. ${ }^{12}$ Ademais, a contabilidade da Companhia de Pernambuco, referente às décadas de 1760 e 1770 estimava uma lucratividade entre 40\% e 25\% sobre as vendas de mercadorias enviadas de Lisboa para Angola. ${ }^{13}$

É verdade, porém, que alguns produtos registraram preços mais baixos em Angola do que em Lisboa. Estas exceções aconselham a não exagerar as diferenças de preços, pois era próprio do negócio com escravos trocar um conjunto de mercadorias pela compra de um grupo de escravos, a perda com um produto poderia ser compensada pela alta margem de outro. Em todo o caso, parece óbvio que Lisboa vendia barato e Luanda comprava caro. Mesmo assim, abstenho-me de qualquer correção, já que a variação de preços entre os dois mercados é uma margem de segurança para o meu argumento.

\footnotetext{
${ }^{11}$ Biblioteca Nacional do Rio de Janeiro (BNRJ), Divisão de Manuscritos, 15,3,33. Manolo Florentino utilizou parte destes dados, mas parece que ele não se deu conta desta particularidade da fonte. $\mathrm{Cf}$. FLORENTINO, Manolo. Tráfico Atlântico, mercado colonial e famílias escravas no Rio de Janeiro, Brasil, c. 1790-ca. 1830. História Questões \& Debates, Curitiba, n. 51, 2009, p. 69-119, aqui, p. 87-88.

${ }^{12}$ Ver fontes da tabela 1.

${ }^{13}$ Arquivos Nacionais Torre do Tombo (ANTT), Companhia Geral de Pernambuco e Paraíba (CGPP), Junta de Lisboa, Livros de Demonstrações, Livros 394 e 395.
} 
Outra incongruência é a distância entre a intenção de venda na metrópole e o gesto na capital de Angola: algumas embarcações podem ter vendido parte da carga em diversos portos africanos, apesar de terem declarado apenas Luanda como destino, superestimando as exportações metropolitanas. Esta distorção se manifesta de modo mais claro quando são desagregadas as categorias de produto: assim, em 1799 e 1804 os valores dos têxteis asiáticos exportados por Portugal superam as importações registradas em Luanda; o mesmo ocorre com o volume de pipas de vinho em 1805. ${ }^{14}$ Tudo indica que este problema é causado pela conjuntura: no período analisado os mercadores portugueses passaram a enviar algumas embarcações para os portos ao norte de Luanda, as balanças registraram estas cargas como exportações para "Angola", mas estas, naturalmente, não eram detectadas pela alfândega de Luanda. Para superar as dúvidas suscitadas por esta distorção, forneço ainda um terceiro método de calcular a participação lisboeta que utiliza fontes diferentes e que estabelece cargas médias para as embarcações originadas no Brasil e em Portugal (ver apêndice).

O mesmo problema com relação ao preço das mercadorias portuguesas existe quando comparo o valor das exportações de Portugal para Angola com o montante de escravos exportados. Deste ponto de vista, o cálculo subestima o "poder de compra" das exportações portuguesas. Não obstante, Angola não exportava apenas pessoas: marfim e cera eram as mercadorias preferidas pelas embarcações que retornavam diretamente à metrópole e compunham $12 \%$ das exportações de Luanda entre 1785 e 1794; deste lado, portanto, o cálculo superestima o poder de compra das exportações portuguesas. ${ }^{15}$

Além disso, há um defeito na definição dos preços dos escravos utilizados, pois eles não são correntes, mas médias decenais estimadas por J. Miller. Comparando as médias de Miller com alguns valores registrados na alfândega de Luanda constata-se que podem existir diferenças positivas e negativas, ainda que para o período entre 1796-1807 os preços da alfândega geralmente superam as médias de Miller; mesmo assim, optei pela série do professor norte-americano porque permite um cálculo completo para o período.

\footnotetext{
${ }^{14}$ É preciso ainda considerar a assincronia entre as partidas do Tejo e as chegadas em Luanda. Em geral, as embarcações portuguesas que faziam comércio na África eram em pequeno número, mas eram de grande tonelagem e carregavam cargas expressivas, assim um veleiro que porventura partisse de Lisboa no final de um ano e chegasse em Angola no início do outro ano provocaria fortes distorções entre os registros portugueses e angolanos. Por isto, acredito que a análise deve ser sempre no agregado, pois o estudo sobre anos isolados não autoriza nenhum tipo de conclusão.

${ }^{15}$ SANTOS, Cocino. O Rio de Janeiro e a Conjuntura Atlântica. Rio de Janeiro: Expressão e Cultura, 1993, p. 156.
} 
Maximiliano Mac MENZ. As "geometrias" do tráfico.

Tudo isto considerado, acredito que os dois cálculos resultam numa aproximação, no agregado, da participação metropolitana no financiamento do resgate de cativos em Luanda. O "valor real" talvez esteja em algum lugar entre as duas estimativas que apresento aqui; ideia que é reforçada pelo cálculo de segurança que apresento em apêndice.

Tabela 1: participação metropolitana no financiamento do tráfico de escravos (em réis)

\begin{tabular}{|c|c|c|c|c|c|}
\hline \multirow[b]{2}{*}{ Ano } & $\mathbf{A}$ & B & $\mathrm{C}$ & \multirow[b]{2}{*}{$\mathbf{A} / \mathbf{B}$} & \multirow[b]{2}{*}{$\mathbf{A} / \mathbf{C}$} \\
\hline & $\begin{array}{l}\text { exportações } \\
\text { portuguesas }\end{array}$ & $\begin{array}{c}\text { importações } \\
\text { angolanas totais }\end{array}$ & $\begin{array}{l}\text { exportações de } \\
\text { escravos }\end{array}$ & & \\
\hline 1796 & 147.576 .210 & & 621.834 .000 & & $24 \%$ \\
\hline 1797 & 126.063 .218 & & 549.427 .000 & & $23 \%$ \\
\hline 1798 & 202.270 .993 & 355.565 .753 & 643.184 .000 & $57 \%$ & $31 \%$ \\
\hline 1799 & 427.829 .486 & 581.280 .590 & 512.034 .000 & $74 \%$ & $84 \%$ \\
\hline 1800 & 444.749 .540 & & 494.710 .000 & & $90 \%$ \\
\hline 1801 & 665.781 .400 & & 618.540 .000 & & $108 \%$ \\
\hline 1802 & 531.446 .477 & 998.801 .831 & 730.658 .000 & $53 \%$ & $73 \%$ \\
\hline 1803 & 480.789 .012 & 995.372 .678 & 874.862 .000 & $48 \%$ & $55 \%$ \\
\hline 1804 & 586.978 .155 & 988.522 .000 & 823.378 .000 & $59 \%$ & $71 \%$ \\
\hline 1805 & 548.620 .485 & 1.063 .412 .000 & 949.953 .000 & $52 \%$ & $58 \%$ \\
\hline 1806 & 597.642 .320 & & 931.165 .000 & & $64 \%$ \\
\hline 1807 & 486.255 .200 & & 741.272 .000 & & $66 \%$ \\
\hline
\end{tabular}

Fontes: A) Exportações portuguesas: 1798: AHMOP, Superintendência Geral dos Contrabandos 5-1, 5-2, 3. Balanças do Comércio do Reino de Portugal com os seus Domínios. 1796-1797, 1799-1807. INEL, Balanças Gerais do Comércio do Reino de Portugal com os seus Domínios e Nações estrangeiras. B) Importações angolanas: 1798 e 1799 AHU, Angola, Avulsos, cx. 89, doc. 79, cx. 93A, doc. 48. 1802-1803, cx. 106, doc. 5, cx. 109, doc. 54. 1804-1805: MILLER, Joseph. Imports at Luanda, Angola 1785-1823. In: PASCH, G.; JONES, A. Figuring African Trade. Berlin: Reimer, 1986, p. 228. C) Exportações de escravos: O número de escravos exportados foi retirado de CURTO, José C. Álcool e Escravos...., op. cit., quadros IV e VIII e multiplicado pelos preços médios de J. Miller. Para o período entre 1796 e 1807 utilizei o preço médio da década de 1800, pois era mais próximo aos dados da alfândega de Luanda. MILLER, Joseph. Slave Prices in..., op. cit., p. 67.

A série sugere que entre 1796 e 1807, e mais particularmente entre 1798 e 1807 a metrópole dominava amplamente o financiamento do tráfico. No agregado, entre 1796 e 1807 as exportações portuguesas equivaleram a perto de $60 \%$ das exportações de escravos e, para os anos em que foi possível comparar, as primeiras foram $56 \%$ das importações totais de Angola. O cálculo de segurança 
no apêndice apresenta uma participação de $54 \%$ da metrópole nas importações totais de Luanda.

\section{As mercadorias do tráfico}

As balanças de comércio lisboetas permitem ainda discutir as classes de mercadorias exportadas para Angola. Há, neste sentido, um total domínio de produtos manufaturados: $86 \%$ das exportações entre 1796 e 1807 eram produtos manufaturados, com especial relevância nos têxteis. Destes, os mais importantes tinham origem asiática (56\%), em segundo lugar vinham os lanifícios $(15 \%)$, muito provavelmente de procedência inglesa em razão do tratado de Methuen. Já os produtos classificados como de fábricas nacionais eram apenas $6 \%$; ou seja, apesar da tendência positiva na produção manufatureira lusitana no período, Portugal não foi capaz de substituir exportações no tráfico de escravos. Trata-se de um vivo contraste com o tráfico inglês, onde as manufaturas de produção nacional gradualmente substituíram os panos de algodão asiáticos. ${ }^{16}$

As exportações de mantimentos portugueses, por causa do vinho, ainda superavam ligeiramente os produtos das fábricas. Bem entendido que não devemos tomar estes dados pelo seu valor de face, pois, como já argumentou Valentim Alexandre, nem todos os mantimentos registrados nas balanças eram de produção nacional portuguesa, enquanto que as categorias "linifícios", "lanifícios" e "metais" não se resumiam a reexportações. Aqui a classificação dos registros de Luanda é mais útil, no intervalo de 1795-1797 os têxteis eram 51\% dos produtos portugueses importados, os manufaturados vários eram $10 \%$ e os produtos ligados à agricultura eram $39 \%$.

Mas, a verdade é que o mercado angolano era realmente irrelevante para as manufaturas portuguesas. Basta comparar os valores das exportações metropolitanas de fazendas produzidas nas fábricas nacionais para Angola (em torno de 340 contos) e para o Brasil (37.480 contos) no período entre 1796 e $1807 .{ }^{17}$ Tampouco tinha importância para a atividade agrícola, pois entre 1796 e 1800

\footnotetext{
${ }^{16}$ Sobre o surto manufatureiro português do final do século XVIII, ver: ARRUDA, José Jobson de. O Brasil no Comércio Colonial. São Paulo: Ática, 1980; ALEXANDRE, Valentim. Os Sentidos do Império: Questão nacional e questão colonial na crise do Antigo Regime português. Porto: Edições Afrontamento, 1993; ALEXANDRE, Valentim. Um momento crucial do subdesenvolvimento português: efeitos económicos da perda do Império Brasileiro, Ler História, n. 7, 1986, p. 3-45; PEDREIRA, Jorge. Estrutura Industrial e Mercado Colonial Portugal e Brasil (17801830). Lisboa: Difel, 1994.

${ }^{17}$ Para os valores das exportações das fábricas para o Brasil, ver NOVAIS, Fernando. Portugal e Brasil na Crise do Antigo Sistema Colonial. São Paulo: Hucitec, 1995, 6 a ed., tabela 29.
} 
as exportações de vinho para a colônia africana equivaliam a aproximadamente $0,34 \%$ das exportações do produto para a Europa. ${ }^{18}$ No apêndice, apresento ainda uma descrição geral dos valores e das classes de produtos exportados de Portugal para Angola.

A classificação do produto sobre a superfície do mercado não permite chegar a grandes conclusões sobre a relação entre o comércio de escravos e os setores da economia portuguesa, pois pouco diz a respeito do seu modo de produção: os manufaturados nacionais exportados por Portugal poderiam ser produzidos de modo artesanal, ou em manufaturas tecnicamente avançadas. Mesmo assim, o caso angolano demonstra que as vantagens comparativas de Portugal, no interior do seu sistema Atlântico, eram as atividades de transformação e não os produtos agrícolas.

A importância dos têxteis asiáticos joga luz sobre outra característica do tráfico metropolitano. Como se observa pela tabela abaixo, grande parte deste tipo de manufatura $-76 \%$ pelo cálculo defeituoso que proponho - utilizada no resgate em Angola vinha em navios originados em Portugal; assim, a tese que afirma o domínio dos mercadores brasílicos sobre o comércio de têxteis em Angola é completamente incorreta no que diz respeito ao período estudado.

Tabela 2

Têxteis asiáticos. exportações de Portugal para Luanda e importações totais de Luanda (em réis)

\begin{tabular}{|c|c|c|c|}
\hline ano & exp. Portugal & imp. Luanda & col.2/ col.3 \\
\hline $\mathbf{( 1 )}$ & $\mathbf{( 2 )}$ & $\mathbf{( 3 )}$ & $\mathbf{( 4 )}$ \\
\hline 1798 & 114.081 .500 & 134.953 .123 & $85 \%$ \\
\hline 1799 & 298.220 .000 & 256.018 .715 & $116 \%$ \\
\hline 1802 & 205.701 .980 & 368.555 .845 & $56 \%$ \\
\hline 1803 & 240.878 .320 & 323.574 .100 & $74 \%$ \\
\hline 1804 & 260.541 .020 & 237.245 .280 & $110 \%$ \\
\hline 1805 & 293.632 .460 & 522.135 .292 & $56 \%$ \\
\hline total & $\mathbf{1 . 2 9 8 . 9 7 3 . 7 8 0}$ & $\mathbf{1 . 7 0 7 . 5 2 9 . 2 3 2}$ & $\mathbf{7 6 \%}$ \\
\hline
\end{tabular}

Fontes: Ver tabela1. A importação total de produtos asiáticos nos anos de 1804 e 1805 foi calculada a partir das porcentagens publicadas por MILLER, Joseph. Imports at Luanda..., op. cit., p. 229.

\footnotetext{
${ }^{18}$ Fonte: MACEDO, Jorge. Problemas de História da Indústria Portuguesa no século XVIII. Lisboa: Querco, 1982, 2ª ed., p. 196; CURTO, José C. Álcool e escravos..., op. cit., Quadro XIII e INEL, Balanças de Comércio.
} 
O comércio de reexportações que era operado a partir de Lisboa só era possível graças ao regime de exclusivo e às restrições do tráfego direto entre as possessões coloniais; mais do que miragem, o exclusivo era o principal mecanismo pelo qual os mercadores metropolitanos podiam ainda controlar o financiamento do resgate em Luanda, pois lhes permitia fornecer, com concorrência limitada, produtos asiáticos e da Europa do norte. Portanto, a vantagem econômica de Lisboa refletia a vantagem política de ser o centro do Império. ${ }^{19}$

\section{As geometrias do tráfico}

Mas, afinal, qual era o traçado das rotas das embarcações que conectavam Portugal a Angola? Apesar do banco de dados Slave Trade Database registrar, na maior parte das vezes, apenas o destino brasileiro das embarcações luso-brasileiras, o estudo serial dos historiadores portugueses Eduardo Frutuoso, Paulo Guinote e Antonio Lopes - sobre a entrada de navios oriundos do Brasil no porto de Lisboa - permite flagrar parte das embarcações em seu retorno ao Tejo.

É presumível que as embarcações que faziam rotas triangulares eram de propriedade de transportadores reinóis. Algumas delas até poderiam pertencer a mercadores de Luanda ou então a sociedades mistas entre diferentes portos; isto, porém, não quer dizer nada, pois não apenas a propriedade de uma embarcação poderia ser extremamente pulverizada, como também os proprietários do casco e das mercadorias dificilmente se confundiam. ${ }^{20}$

\footnotetext{
${ }^{19}$ O que contrasta com o negócio na Costa da Mina onde o resgate era livre, de modo que os comerciantes portugueses só podiam oferecer o tabaco (ou ouro) para competir com os mercadores da Europa, traduzindo-se numa vantagem aos homens de negócio residentes na colônia. Cf. LOPES, Gustavo Acioli; MENZ, Maximiliano M. Resgate e Mercadorias..., op. cit.; LOPES, Gustavo Acioli. Negócio da Costa da Mina..., op. cit.

${ }^{20}$ Em 1811 Manuel Pinto Coelho relatava que dos proprietários das embarcações que faziam tráfico em Angola, seis pertenciam à praça de Luanda, seis à praça do Rio de Janeiro, um era de Pernambuco e dois da Bahia. (IHGB, DL 1132.5, Manuel Pinto Coelho, 10/04/1811). Trata-se, porém, do período pós 1808 . Sobre a característica do negócio de transporte de mercadorias Cf. DAVIS, Ralph. The Rise of the English Shipping Industry. London: MacMillan, 1962; COSTA, Leonor. O Transporte no Atlântico e a Companhia Geral do Comércio do Brasil, 1580-1663. Lisboa: CNCDP, 2002. Note que os dois autores afirmam que no tráfico a propriedade da carga e da embarcação se confundiam, mas isto não ocorria no comércio luso-brasileiro de escravos do final do século XVIII.
} 
Maximiliano Mac MENZ. As "geometrias" do tráfico.

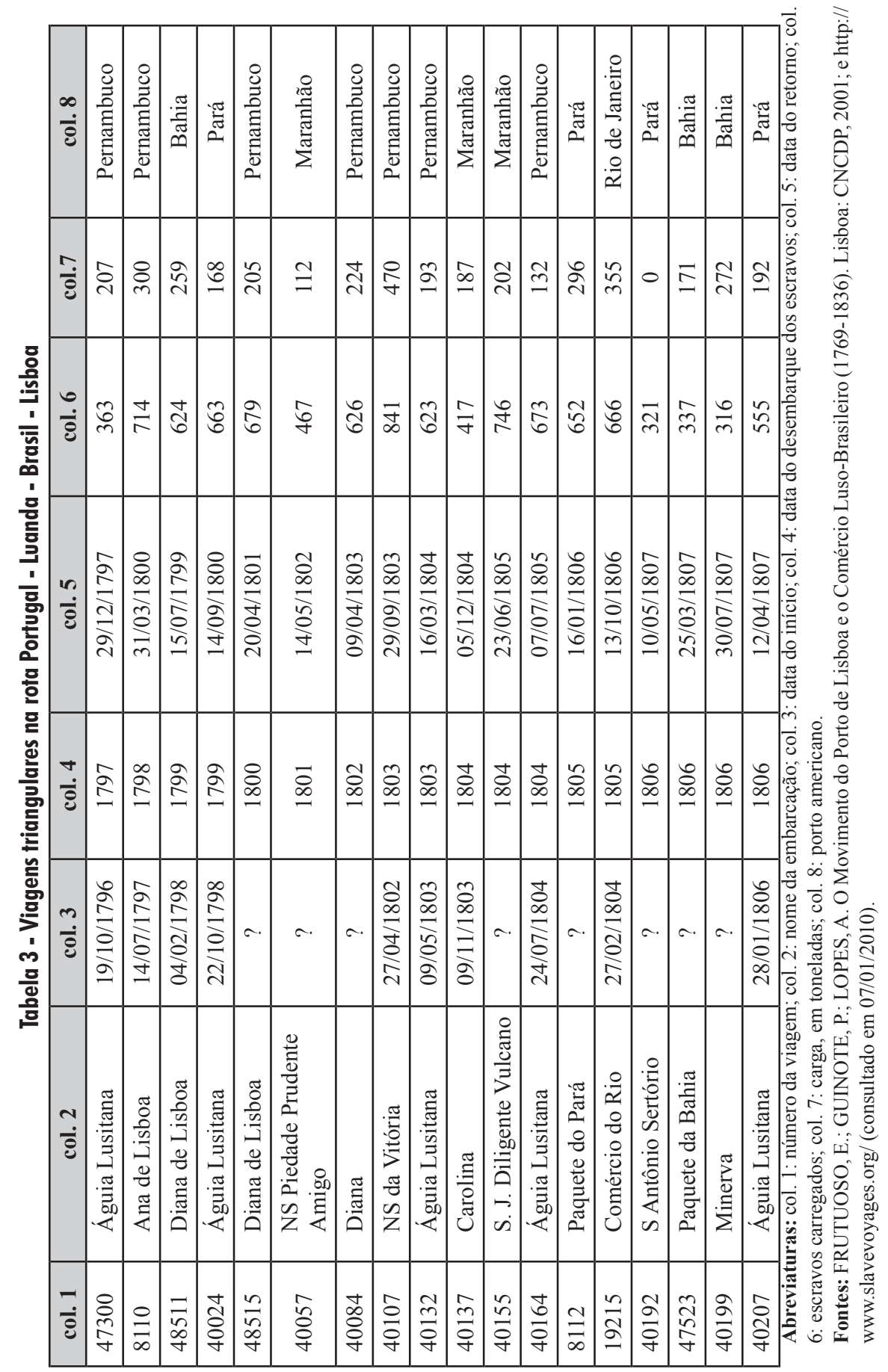


A tabela 3 é o resultado do cruzamento destas duas bases de dados; as colunas 1, 2, 3, 4 e 6 têm origem no Database, já as colunas 5, 7 e 8 foram retiradas do estudo dos pesquisadores portugueses. Não se trata de um levantamento exaustivo, pois registra apenas as embarcações em que constavam os mesmos mestres nas duas bases de dados. Ademais a tabela inclui apenas as naves que mantiveram uma rota estrita, passando por Luanda e necessariamente terminando a viagem na capital portuguesa. Perdem-se, por este recorte, as embarcações que podem ter preferido um porto português diferente como ponto de retorno; outro problema é que esta descrição uniformiza viagens que podem ter sido mais erráticas, incluindo partidas em um porto americano ou africano.

Desse modo, entre as 40 viagens registradas no Database que seguiram a rota Portugal-Luanda-Brasil no período de 1796-1807, encontramos 18 que terminaram o percurso em Lisboa com o mesmo mestre. Os destinos das 22 viagens restantes podem ter sido os mais diversos: a troca do mestre, o retorno a outro porto português, a demora demasiada no Brasil, o estabelecimento de uma rota diferente (Brasil-Portugal-Luanda-Brasil ou então Portugal-LuandaBrasil-Luanda), a venda da embarcação no Atlântico-sul, a perda do navio por acidente, etc.

A primeira conclusão é que apesar da frequência ser baixa, as rotas triangulares ocorreram, incluindo o retorno com cargas de produtos coloniais para Portugal. A tabela demonstra ainda que o tráfico triangular estava conectado principalmente às regiões de Pernambuco, Grão Pará e Maranhão. Esta parece ser uma tendência geral do tráfico metropolitano durante o período, pois as 40 viagens triangulares registradas no Database carregaram escravos principalmente para a região da Amazônia e para Pernambuco (tabela 4).

Tabela 4: escravos embarcados em Angola por destino

\begin{tabular}{|l|c|c|c|}
\hline \multicolumn{1}{|c|}{ Região } & navios portugueses & total & $\%$ \\
\hline Amazônia & 6.811 & 12.163 & $56 \%$ \\
\hline Bahia & 2.019 & 26.106 & $8 \%$ \\
\hline Pernambuco & 8.334 & 31.346 & $27 \%$ \\
\hline Sudeste Brasil & 5.333 & 74.118 & $7 \%$ \\
\hline
\end{tabular}

Fonte: ver nota 10. 


\section{Maximiliano Mac MENZ. As "geometrias" do tráfico.}

A distribuição das rotas pode ser interpretada pela exclusão: as comunidades mercantis das praças de Bahia e do Rio, bem estabelecidas no tráfico, dominariam o transporte de escravos em suas regiões, mas é importante considerar uma continuidade dos capitais lisboetas ligados às antigas companhias pombalinas. Esta distribuição também pode sugerir que os traficantes metropolitanos atuavam nos mercados mais dinâmicos que, entre 1796 e 1807, atravessavam uma forte expansão nas exportações, principalmente por causa do algodão. ${ }^{21}$

No total, a participação metropolitana no carregamento de escravos para a colônia entre 1796 e 1807 foi insignificante. Segundo o Transatlantic Slave Trade Database as embarcações que haviam partido do Brasil continuavam a dominar de modo amplo o mercado de fretes dos escravos: $84 \%$ dos cativos embarcados em Luanda navegaram em embarcações que tinham origem em portos do Brasil. ${ }^{22}$ Número que contrasta explicitamente com os dados da tabela 1, pois a alta participação metropolitana no mercado angolano de importações deveria ter alguma correspondência no mercado de exportações de escravos.

Mas não era o que ocorria: dividindo o valor das exportações portuguesas que constam nas Balanças de Comércio pelo número de barcos originados em Portugal que deram entrada em Luanda, sabemos que o valor médio das cargas dos navios metropolitanos era de 73 contos de réis, o que permitiria comprar aproximadamente 1.211 escravos em Luanda; contudo, estes navios carregavam para o Brasil, em média, apenas 562 escravos de acordo com o Database. ${ }^{23}$

A Balança de Comércio entre Portugal e Angola aparentemente aprofunda o paradoxo, pois enquanto Portugal exportou mercadorias no valor de 5.246.002.496 réis, importou apenas 77.091.026 réis, basicamente cera e marfim. Portugal, portanto, acumulou um saldo positivo absurdo (e, por conseguinte, Angola um saldo negativo) de 5.168.911.470 réis. A análise desagregada mostra que a tendência de saldos positivos para a metrópole manteve-se de modo uniforme entre todo o período estudado. Ou seja, não era com exportações ou remessa direta de moeda que Angola equilibrava seu saldo com Portugal.

\footnotetext{
${ }^{21}$ Sobre a expansão exportadora nestas regiões e o papel do algodão ver ARRUDA, José Jobson de. $O$ Brasil no comércio colonial. op. cit.; PALACIOS, Guillermo. Cultivadores Libres, Estado y Crisis de la Esclavitud en Brasil en la Época de la Revolución Industrial. Ciudad de Mexico: FCE, 1998.

${ }^{22}$ Não é possível concluir nada desta variação de $91 \%$ no século XVIII para $84 \%$ no período de 1796-1807, pois as fontes do Database são demasiadamente aleatórias.

${ }^{23}$ Fontes: exportações portuguesas, números e preços de escravos ver fontes da tabela 1 . Números de escravos carregados pelas embarcações originadas em Portugal, ver nota 10.
} 
Tabela 5: balança comercial entre Portugal e Angola (em réis)

\begin{tabular}{|l|r|r|l|}
\hline ano & exportação & \multicolumn{1}{l|}{ importação } & \multicolumn{1}{l|}{ saldos } \\
\hline 1796 & 147.576 .210 & 16.408 .250 & 131.167 .960 \\
\hline 1797 & 126.063 .218 & 0 & 126.063 .218 \\
\hline 1798 & 202.270 .993 & 20.481 .250 & 181.789 .743 \\
\hline 1799 & 427.829 .486 & 7.155 .000 & 420.674 .486 \\
\hline 1800 & 444.749 .540 & 4.728 .600 & 440.020 .940 \\
\hline 1801 & 665.781 .400 & 0 & 665.781 .400 \\
\hline 1802 & 531.446 .477 & 10.942 .125 & 520.504 .352 \\
\hline 1803 & 480.789 .012 & 2.336 .000 & 478.453 .012 \\
\hline 1804 & 586.978 .155 & 7.307 .800 & 579.670 .355 \\
\hline 1805 & 548.620 .485 & 3.241 .000 & 545.379 .485 \\
\hline 1806 & 597.642 .320 & 2.149 .001 & 595.493 .319 \\
\hline 1807 & 486.255 .200 & 2.342 .000 & 483.913 .200 \\
\hline total & $\mathbf{5 2 4 6 0 0 2 4 9 6}$ & $\mathbf{7 7 . 0 9 1 . 0 2 6}$ & $\mathbf{5 . 1 6 8 . 9 1 1 . 4 7 0}$ \\
\hline
\end{tabular}

Fontes: INEL, Balanças Gerais do Comércio do Reino de Portugal com os seus Domínios e Nações estrangeiras (1796-1807); e AHMOP, Superintendência Geral dos Contrabandos 5-1, 5-2, 3.

Ora, desde David Ricardo sabe-se que as balanças de pagamentos em economias baseadas em moeda metálica tendem a se equilibrar no médio prazo. Portanto, supõe-se que Angola deveria necessariamente obter saldos positivos sobre o seu outro parceiro comercial tradicional, o Brasil. E, de fato, se observarmos a balança geral de Angola, baseada nos registros alfandegários de Luanda, constata-se que a tendência geral do comércio angolano era positiva; ou seja, dada a tendência negativa do comércio angolano com a metrópole, tais superávits só poderiam ser sustentados com saldos altíssimos sobre o Brasil (ver ainda a tabela 7). 
Maximiliano Mac MENZ. As "geometrias" do tráfico.

Tabela 6: exportações e importações (totais) de Angola de acordo com os registros de Luanda (réis)

\begin{tabular}{|l|r|r|r|}
\hline \multicolumn{1}{|c|}{ ano } & \multicolumn{1}{c|}{ exportação } & \multicolumn{1}{c|}{ importação } & \multicolumn{1}{c|}{ saldos } \\
\hline $1785-1794$ & 6.225 .789 .268 & 4.868 .872 .930 & 1.356 .916 .338 \\
\hline $1795-1797$ & 2.088 .558 .375 & 1.773 .005 .010 & 315.553 .365 \\
\hline 1798 & 674.669 .580 & 355.565 .753 & 319.103 .827 \\
\hline 1799 & 828.057 .880 & 581.280 .590 & 246.777 .290 \\
\hline 1802 & 833.815 .280 & 998.801 .831 & $(164.986 .551)$ \\
\hline 1803 & 987.685 .500 & 995.372 .678 & $(7.687 .178)$ \\
\hline 1804 & 985.587 .000 & 988.522 .000 & $(2.935 .000)$ \\
\hline 1805 & 1.076 .159 .000 & 1.063 .412 .000 & 12.747 .000 \\
\hline 1808 & 831.244 .660 & 825.226 .958 & 6.017 .702 \\
\hline 1809 & 791.645 .780 & 588.991 .753 & 202.654 .027 \\
\hline Total & $\mathbf{1 5 . 3 2 3 . 2 1 2 . 3 2 3}$ & $\mathbf{1 3 . 0 3 9 . 0 5 1 . 5 0 3}$ & $\mathbf{2 . 2 8 4 . 1 6 0 . 8 2 0}$ \\
\hline
\end{tabular}

Fontes: 1785-1794, dados totais copilados por Corcino Santos. O Rio de Janeiro e a Conjuntura Atlântica. Rio de Janeiro: Expressão e Cultura, 1993, p. 156. 1795-1797, BNRJ, 15,3,33. 1798 e 1799, AHU, Angola, Avulsos, cx. 89, doc. 79, cx. 93A, doc. 48. 1802-1803, cx. 106, doc. 5, cx. 109, doc. 54. 1804-1805: MILLER, Joseph. Imports at Luanda..., op. cit., p. 228. 1808-1809, Arquivo Nacional (AN), Real Junta de Comércio (RJC), cx. 448 , pct. 1.

Mesmo assim, a demonstração dos superávits sobre o Brasil não basta para resolver a questão, pois como já sabemos as embarcações originadas na metrópole carregavam uma parte pequena dos escravos exportados. Era necessário, portanto, existir algum mecanismo financeiro que permitisse transferir o saldo positivo angolano com o Brasil para Portugal, de maneira a equilibrar a balança comercial de Angola com a Metrópole.

Como pioneiramente destacou Joseph Miller, as importações angolanas desde Lisboa eram saldadas por letras, pois os homens de negócio de Lisboa preferiam evitar o risco das perdas na middle passage. ${ }^{24}$ Assim, os mercadores de Luanda lançavam em seu nome letras para serem sacadas sobre os homens de negócio residentes no Brasil, sobre o produto da venda de seus escravos. As letras poderiam ser trocadas no Brasil por ouro ou mercadorias; através deste negócio, o valor das mercadorias para o resgate na Costa da África transformava-se em

${ }^{24}$ MILLER, Joseph. Way of Death..., op. cit., p. 299-301, 537. Diversos documentos coevos comprovam esta prática para o pagamento dos contratadores: ver, por exemplo, BNRJ, I-32,34,032 $\mathrm{n}^{\mathrm{o}}$ 001; AHU, Avulsos, Pernambuco, doc. 8074, cx. 104, 18/03/1764. 
remessas líquidas de ouro para Portugal ou então em outros produtos coloniais como açúcar, algodão e tabaco.

Pelos números reunidos até aqui é possível estimar que apenas $28 \%$ das exportações portuguesas para Angola, entre 1796 e 1807, foram pagas imediatamente com mercadorias (escravos enviados para o Brasil em embarcações portuguesas, mais a cera e o marfim exportados para Portugal), o restante foi pago com letras. ${ }^{25}$ Por conseguinte, grande número dos escravos carregados por embarcações originárias dos portos do Brasil foi adquirido no sertão africano graças às mercadorias fornecidas pelos mercadores metropolitanos. Vale dizer que, mesmo nas rotas triangulares completas, as letras podem ter sido utilizadas para pagamento dos escravos, pois não é improvável que os escravos e as cargas de retorno para Portugal estivessem sendo carregados em frete pelos navios negreiros. ${ }^{26}$

O triângulo financeiro do tráfico angolano manifesta-se também na balança comercial entre Portugal e o Brasil, especialmente se desagregada por região. Enquanto que no Rio de Janeiro as remessas de ouro e prata para o Reino superavam os saldos (negativos) desta praça, nas regiões norte os superávits comerciais obtidos sobre a metrópole eram muito superiores à quantidade de moeda que efetivamente vinha de Portugal. Na capital do Brasil, a exportação do ouro-mercadoria para Portugal saldava de uma só vez os déficits do Rio com Angola e de Angola com o Reino. Nas regiões ao norte eram os produtos como açúcar e algodão que geravam um superávit sobre Portugal que, no entanto, não era saldado apenas com moedas, mas também com escravos (ver mapas). ${ }^{27}$

\footnotetext{
${ }^{25}$ Valor dos escravos exportados em embarcações portuguesas (22.497 segundo o Database) estimado em 1.372.317.000 réis, utilizando os mesmos critérios de cálculo da tabela 1. Para os demais valores e fontes ver tabela 5. É verdade, porém, que os números do Database estão incompletos, por isto a porcentagem do pagamento com mercadorias deve ter sido ligeiramente maior.

${ }^{26} \mathrm{O}$ mesmo costumava ocorrer com o tráfico de escravos inglês. Cf. MINCHINTON, Walter E. The Triangular Trade Revisited. In: GEMERY, Henry A.; HOGENDORN, Jan S. (Eds.). The Uncommon Market. Essays in the Economic History of Atlantic Slave Trade. Nova York: Academic Press, 1979, p. 343.

${ }^{27}$ Para os dados da balança entre Portugal e o Brasil ver ARRUDA, José Jobson de. O Brasil no comércio colonial. op. cit. No entanto, utilizo o método de Valentim Alexandre para calcular déficits e superávits. ALEXANDRE, Valentim. Os sentidos do Império..., op. cit.
} 
Maximiliano Mac MENZ. As "geometrias" do tráfico.
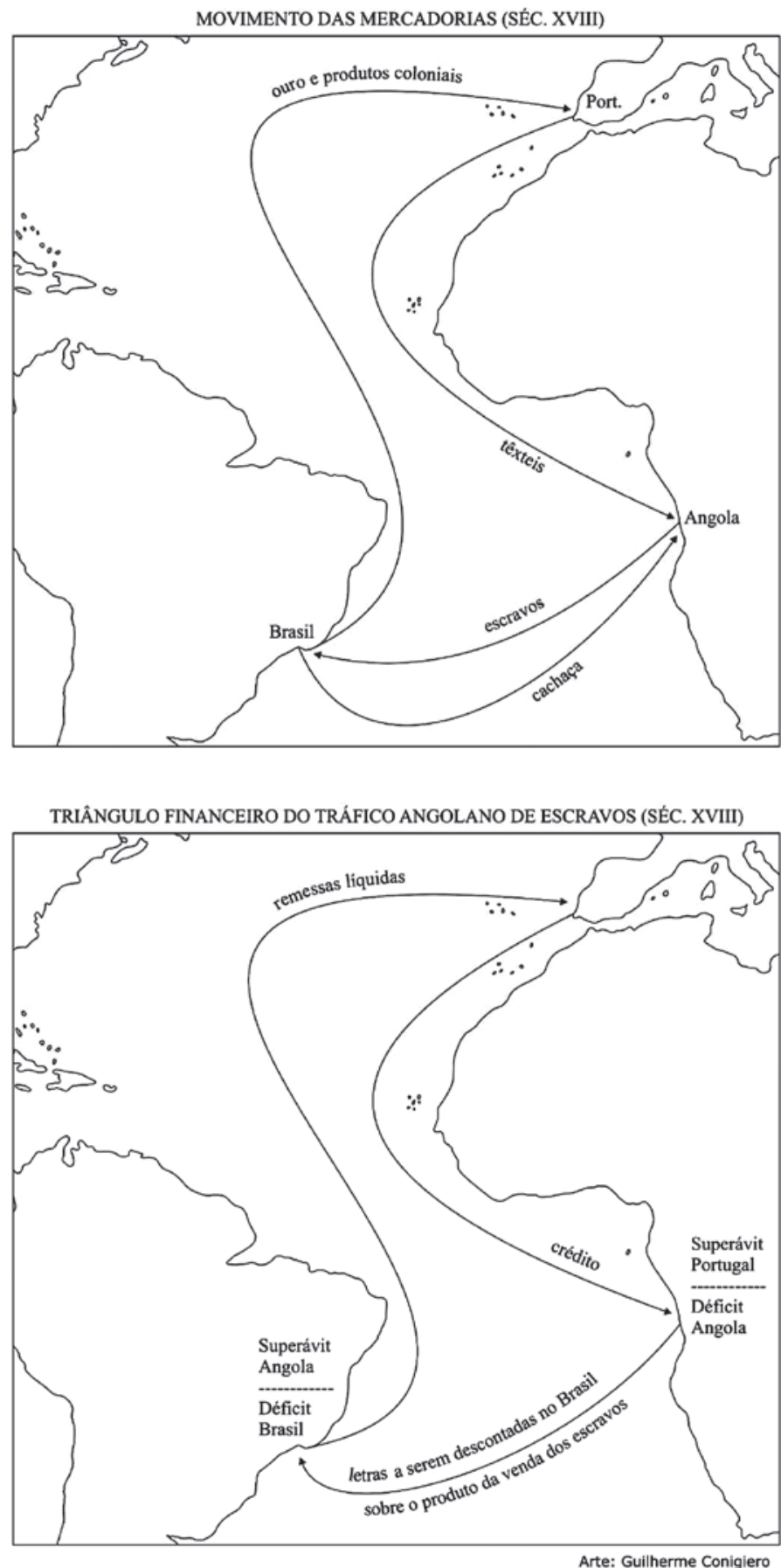

Revista de História, São Paulo, n. 166, p. 185-222, jan./jun. 2012 
Todavia, é importante esclarecer alguns pontos sobre a organização financeira do negócio de escravos no final do século XVIII, de modo a destacar esta conjuntura das demais.

Na década de 1760 as operações de crédito eram controladas pelos arrematadores lisboetas do contrato da cobrança de impostos sobre as exportações de escravos desde Luanda e do monopólio do marfim. Os contratadores também controlavam o meio circulante da capital angolana, fornecendo créditos, as livranças, que eram utilizadas como papel moeda pela população da capital e pelos mercadores de escravos que trocavam letras seguras sobre o Brasil por este papel moeda.

As referências documentais a respeito do controle exercido por estes financistas sobre o comércio de escravos são muitas: em 1758 o Alvará de 11 de janeiro atacava os monopólios de "certas e determinadas pessoas" sobre o comércio angolano. ${ }^{28}$ Em 1769 seria a vez da Mesa de Inspeção da Bahia se referir “(...) à iniquidade do monopólio dos contratadores e administradores das Rendas Reais de Angola". ${ }^{29}$

Por sua vez, o governador de Angola D. Francisco de Souza Coutinho afirmava que

(...) a íntima e estreita união que a Administração deste contrato formou desde o princípio com os povos, faz com que ela influa bastante na causa pública, porque nem os povos podem comerciar sem o contrato, nem este lucrar sem o trabalho e os suores do povo (...). ${ }^{30}$

Neste sentido, acusava particularmente o contratador Domingos Dias por fornecer crédito aos mercadores angolanos, exigindo o pagamento em ouro no Brasil. Também uma longa memória anônima afirmava que os contratadores monopolizavam o resgate, fornecendo crédito a apenas duas casas de negócio, de Tomé da Silva Coutinho e Manoel da Silva, ligadas aos administradores do contrato:

Foi tão grande este monopólio que desde o ano de 1763 até o 1768 só aquelas duas casas vendiam fazendas para os sertões e deles recebiam remessas de cera, marfim e escravos,

\footnotetext{
${ }^{28}$ Alvará de 11 de janeiro de 1758 em Ius Lusitaniae - Fontes Históricas do Direito Português. Disponível em: http://iuslusitaniae.fcsh.unl.pt ; consultado em 16/04/2010.

${ }^{29}$ AHU, Avulsos, Coleção Castro de Almeida (CA)-Bahia, doc. 8123, cx. 44, 20/12/1769.

${ }^{30}$ Instituto de Estudos Brasileiros (IEB), Correspondência de D. Francisco de Souza Coutinho, Coleção Lamego, Códice 82, doc. 426, 20/08/1768.
} 


\section{Maximiliano Mac MENZ. As "geometrias" do tráfico.}

de tal sorte que tinham este comércio como fechado em todo o tempo do governador D. Antonio de Vasconcelos. ${ }^{31}$

Também a Companhia de Pernambuco era uma forte operadora no comércio de escravos em Angola, sendo responsável pela exportação de $26 \%$ dos cativos enquanto durou seu monopólio. ${ }^{32}$

Mas o fim do contrato no ano de 1770 interrompeu este tipo de articulação financeira. Ao receber a notícia do fim do contrato, D. Francisco de Souza Coutinho manifestava o receio de que o comércio fosse afetado pela falta de financiamento. Por isto, esperava que a Junta de Comércio de Lisboa e as Companhias de Comércio “(...) devem dar uma regular navegação das fazendas próprias ao resgate de escravos, ou a certa e segura escala das Naus da Índia, porque de outra maneira perecerá o comércio". ${ }^{33}$

Enviava ainda um cálculo da Junta de Fazenda de Angola sobre a quantidade de mercadorias necessárias para fazer o resgate que permite demostrar o domínio avassalador dos capitais lisboetas. Segundo os membros da Junta, o produto anual das embarcações com origem nos portos brasileiros era de 160 contos (28\%), restando aí 404 contos que deveriam ser completados por embarcações vindas de Lisboa. $^{34}$

No entanto, apenas dois anos depois as naus das Índias foram proibidas de desembarcar mercadorias no porto de Luanda sob a justificativa de que este negócio “(...) estabelecido por meio do interposto de Angola, um comércio geral e navegação entre a Ásia, África e América, com total exclusão destes Reinos (...)". ${ }^{35}$ Ademais, cinco anos depois, as Companhias de Comércio perderam os seus privilégios, o que pode ter provocado, junto com o fim do contrato, uma retração dos capitais lisboetas. Como já foi dito, a opinião de Joseph Miller é que a partir de 1780 ocorreu uma forte penetração dos mercadores do Brasil no comércio angolano, facilitada pela retirada dos homens de negócio metropolitanos. ${ }^{36}$

${ }^{31}$ BNRJ, Divisão de Manuscritos, I-32,34,032, no 001.

${ }^{32}$ Cf. MENZ, Maximiliano M. A Companhia de Pernambuco e o funcionamento do tráfico de escravos em Angola. (artigo inédito), 2011.

${ }^{33}$ IEB, Coleção Lamego, Códice 82, doc., Francisco Inocencio Coutinho, 03/02/1770.

${ }^{34}$ AHU, cx. 54, doc. 28, Avulsos, Angola, 03/06/1770. Anexada à correspondência de D. Francisco de Souza Coutinho.

${ }^{35}$ Alvará de 19 de junho de 1772, em Ius Lusitaniae - Fontes Históricas do Direito Português, disponível em: http://iuslusitaniae.fcsh.unl.pt ; consultado em 08/04/2009.

36 "The Brazilians found the field in Africa wide open, in part because Lisbon merchants effectively withdrew from the Angola trade after the death of the king Dom José I and dismissal of his chief minister, the Marquis of Pombal (...)". MILLER, Joseph. Way of Death..., op. cit., p. 491-492. 
De fato, os testemunhos de Martinho de Mello e Castro e mais tarde do governador de Angola, o Barão de Mossâmedes, apontam nesta direção. Martinho de Mello relacionava a "decadência" do comércio reinol ao crescimento do contrabando francês, à vantagem dos produtos brasileiros e ao comércio direto da Ásia com Brasil e Angola. Os números de passaportes retirados em Lisboa para viagens a Angola confirmam a retração metropolitana na década de $1770 .{ }^{37}$

Por outro lado, existem indícios, ainda que pouco claros, de uma transformação na composição das cargas com o decorrente crescimento da participação brasílica no fornecimento de mercadorias; como dizia o Barão de Mossâmedes, "as embarcações da carreira da América que têm aqui a predileção dos naturais e que trazem com o primeiro gênero de negócio de resgate a jeribita sortida com toda a casta de fazendas". ${ }^{38}$

No entanto, dois anos mais tarde, o mesmo Môssamedes escrevia:

Se acha esta praça muito desanimada, pelas péssimas vendas de todo o Brasil e empate de cabeças no Rio de Janeiro, aonde sempre tiveram o maior consumo e se remetiam as letras ou efeitos, terminando o giro com os dinheiros de risco, com a realizar-se tudo na Metrópole. $^{39}$

Afinal, não se tratou de uma retração definitiva; na década de 1780 e início da de 1790 as saídas de embarcações metropolitanas oscilam bastante, até que, no final do século XVIII, estas voltaram a frequentar o porto de Luanda de modo mais amiúde. $\mathrm{O}$ domínio metropolitano sobre o crédito neste período é confirmado pelo governador de Angola D. Miguel Antonio de Mello, que fez o seguinte comentário a respeito da comunidade mercantil de Luanda:

À exceção de três ou quatro negociantes, todos os mais desta praça possuem tão pequeno cabedal próprio, que para sustentarem o comércio que fazem e entretem recorrem ao meio de mandarem tomar na de Lisboa dinheiro a risco e com bom prêmio, com os quais compram fazendas que para aqui conduzem, ou mandam vir obrigando-se a pagar dentro de certo tempo a seus credores o principal e juros. ${ }^{40}$

\footnotetext{
${ }^{37}$ AHU, Avulsos, Angola, cx. 62, doc. 57, minuta de Martinho de Mello e Castro, 22/06/1779 e AHU, CU, Códices (passaportes), 774, 775, 776, 777, 778, 779, 780, 781, 782, 783, 784, 785, 786, 787.

${ }^{38}$ AHU, Avulsos, Angola, cx. 71, doc. 52, Barão de Mossâmedes, 15/10/1786.

39 AHU, Avulsos, Angola, cx. 73, doc. 16, Barão de Mossâmedes, 15/03/1788.

${ }^{40}$ BNRJ-22,2,50, Oficios do Governador de Angola, Miguel Antonio de Mello, 30/01/1801.
} 
Creio que a explicação para esta nova conjuntura está na retirada dos navios franceses que faziam uma forte concorrência na África Centro-Ocidental, nas oportunidades de comércio com os espanhóis e na recuperação dos preços dos escravos no Brasil. Assim, em minha opinião, e ao contrário do que afirma Miller, a retração lisboeta foi apenas passageira.

Seja como for, o crédito continuava tendo uma origem principal: a capital do Império. Mas esta dependência financeira do tráfico quanto ao crédito lisboeta estava articulada institucionalmente de um modo diferente ao da década de 1760, dado o fim do contrato sobre o imposto de exportação de escravos. Problema a ser discutido em outro lugar: a correspondência do governador de Angola, nos últimos anos do século XVIII, indica que a Junta de Fazenda da colônia africana ocupou o lugar dos contratadores, fornecendo letras a serem descontadas sobre as Mesas de Inspeção das praças brasileiras. ${ }^{41}$

\section{0 Brasil e o tráfico}

Em 1758 o governador da capitania de Pernambuco, Luis Diogo Lobo da Silva, escreveu para a Corte relatando a fiscalização feita aos navios negreiros quanto da sua lotação. Comentando o hábito dos capitães de navio de superlotar as embarcações, acrescentou a importante reflexão:

(...) atendendo a pouca utilidade que fazem nos gêneros que remetem para Angola, pela excessiva quantidade jeribitas que nela introduzem, lhes fica sendo o frete de seis mil réis limitado a poderem conservar as embarcações pelas despesas que fazem, o que parece justo que S. Maj. atenda aumentando-lhes o que o mesmo Snr. julgar conforme nas presentes circunstâncias, ou regulando em Angola os preços dos ditos escravos (...). ${ }^{42}$

O comércio de jeribitas e o frete eram as principais fontes de renda dos mercadores daquela praça que atuavam no tráfico de escravos. Sobre as cachaças muito já se escreveu; sabe-se que era o principal produto de origem brasileira utilizado no tráfico em Angola e, portanto, a mercadoria mais importante no ramo "brasílico" do tráfico; acrescentarei ainda mais algumas considerações a este respeito logo em seguida. ${ }^{43}$ No entanto, poucos têm abordado o fretamento

${ }^{41}$ BNRJ-22,2,50, Seção de Manuscritos, Ofícios do Governador de Angola, Miguel Antonio de Mello, 24/07/1800.

${ }^{42}$ AHU, Avulsos, Pernambuco, doc. 7129, cx. 89, Luis Diogo Lobo da Silva, 12/11/1758.

${ }^{43}$ Ver CURTO, José C. Álcool e escravos..., op. cit.; ALENCASTRO, Luiz Felipe de. O Trato dos viventes..., op. cit. Para uma crítica a respeito da sobrevalorização da jeribita nas importações totais angolanas, ver LOPES, Gustavo Acioli; MENZ, Maximiliano M. Resgate e Mercadorias..., op. cit. 
dos escravos por parte das embarcações com origem nos portos do Brasil. Para o consenso trata-se de um falso problema, pois cargas e embarcações são tratadas indiscriminadamente como propriedade da mesma pessoa, em geral dos mercadores das praças brasileiras. ${ }^{44}$

Mas é justamente o fretamento que permite compreender a discrepância entre o domínio metropolitano sobre as importações angolanas e a baixa frequência das embarcações reinóis no carregamento de escravos. De fato, segundo J. Miller a maior parte dos escravos carregados ao Brasil pertencia a mercadores de Luanda que pagavam o frete aos capitães das embarcações brasileiras - e as importações de mercadorias do Reino - com o produto da venda destes cativos no litoral americano. ${ }^{45}$

Os números dos mapas de exportação e importação das praças da Bahia confirmam o fretamento. É importante, porém, fazer algumas ressalvas: os referidos mapas são bem menos completos que os registros portugueses ou seus similares angolanos; trata-se apenas de uma descrição bem geral dos produtos exportados. As mercadorias da terra, cachaça e açúcar, estão relativamente bem discriminadas; geralmente também consta uma coluna de "mercadorias europeias", ou então "mercadorias de Portugal" ou apenas "mercadorias".

Um último problema em relação aos dados da alfândega da Bahia, apesar de algumas vezes constar apenas Angola em mapas isolados (por exemplo, os de 1797, 1798 e 1799), as entradas e saídas de embarcação e os "Mapas Gerais", que sumariam exportações e importações da Bahia entre 1798 e 1807, indicam a inclusão de Benguela neste registro. ${ }^{46}$

Por último, remeto o leitor às ressalvas feitas em relação aos dados de Lisboa, pois os problemas dos preços e da incerteza quanto ao destino final das mercadorias também se verificam nos mapas de exportação do Brasil.

\footnotetext{
${ }^{44}$ Inclusive Manolo Florentino conclui pelo domínio dos mercadores "cariocas" sobre o tráfico a partir da declaração dos consignatários das cargas no porto do Rio de Janeiro, que constam nos jornais após 1808 .

${ }^{45}$ MILLER, Joseph. Way of Death..., op. cit., passim.

${ }^{46}$ Mas no ano de 1797 seguramente só foi registrado comércio com Angola.
} 
Maximiliano Mac MENZ. As "geometrias" do tráfico.

Tabela 7: comércio da Bahia com Angola e Benguela (réis)

\begin{tabular}{|c|r|r|r|}
\hline ano & exportações & importações & \\
\hline 1797 & 19.488 .760 & 67.400 .000 & -35.911 .240 \\
\hline 1798 & 47.000 .000 & 216.880 .000 & -169.880 .000 \\
\hline 1799 & 62.674 .640 & 132.480 .000 & -69.805 .360 \\
\hline 1800 & 32.400 .000 & 198.800 .000 & -166.400 .000 \\
\hline 1801 & 30.716 .000 & 146.960 .000 & -116.244 .000 \\
\hline 1802 & 41.100 .520 & 315.080 .000 & -273.979 .480 \\
\hline 1803 & 46.073 .980 & 287.040 .000 & -240.966 .020 \\
\hline 1804 & 73.600 .500 & 209.440 .000 & -135.839 .500 \\
\hline 1805 & 57.892 .800 & 195.600 .000 & -137.707 .200 \\
\hline 1806 & 36.093 .900 & 33.704 .000 & 2.389 .900 \\
\hline 1807 & 67.021 .200 & 175.920 .000 & -108.898 .800 \\
\hline total & $\mathbf{5 2 6 0 6 2 3 0 0}$ & $\mathbf{1 9 7 9 3 0 4 0 0 0}$ & $\mathbf{- 1 . 4 5 3 . 2 4 1 . 7 0 0}$ \\
\hline
\end{tabular}

Fontes: 1797, Arquivo Público do Estado da Bahia (APEB), Registro da Correspondência Expedida para o Rei; 1794-1797, Vol. 138. 28/02/1798. 1798-1807, BNRJ, Seção de Manuscritos, I-17,12,4, nº 2.

A primeira e mais óbvia conclusão é que a Bahia acumula déficits com as praças luso-africanas; 1806 é o único ano "fora da curva", possivelmente pelo fim da paz de Amiens. Nas contas agregadas do tráfico, a balança de comércio negativa da Bahia conecta-se perfeitamente com a balança de comércio positiva de Portugal sobre Angola e o comércio angolano superavitário em geral (ver tabelas 5 e 6 ).

Pode-se argumentar, entretanto, que os déficits baianos são falsos, pois não estão contabilizadas as diferenças de preços e os custos de operação. No ano de 1797 constam ainda 12 contos de réis de "promptificação do transporte e beneficio". ${ }^{47}$ Ou seja, o autor do mapa calculava que os custos, os lucros e, muito provavelmente, os fretes de retorno gerariam um valor $62 \%$ superior ao exportado. Já na nota ao mapa de 1798 afirmava o escrivão que "Estes gêneros devem produzir pelas suas vendas ao menos $40 \%$ para salvar seguros de mar, corsários, fretes avultados e algum beneficio (...)" ${ }^{48}$ Mesmo assim, se somados qualquer um destes valores às exportações, os déficits permanecem expressivos.

${ }^{47}$ APEB, Registro da Correspondência Expedida para o Rei, 1794-1797, Vol. 138. Descontei estes 12 contos das exportações para uniformizar os valores.

${ }^{48}$ AHU, Avulsos, CA, Bahia, docs. 18375-18379, 25/08/1798. 
Portanto, estes déficits comprovam o desenho financeiro do tráfico de Angola proposto aqui e, dada a baixa frequência das rotas triangulares que tinham a Bahia como escala (ver tabela 4), apontam para a importância da prática de fretamento dos escravos. Fortalecem ainda a minha hipótese que os mercadores de Lisboa dominavam o financiamento do resgate de escravos em Luanda, afinal, estes déficits, sem a decorrente remessa de moeda ${ }^{49}$, só podem ser explicados se considerarmos que a Bahia pagava parte da importação de escravos não com a remessa de produtos para a África, mas enviando moeda ou mercadorias para o Reino. ${ }^{50}$

É notável também o padrão das exportações baianas para Angola e para Benguela: dos seis anos em que foi possível consultar os mapas individualizados, apenas em 1798 constatam-se exportações vigorosas de produtos da terra, especialmente a cachaça. Nos outros anos há um total domínio das mercadorias de origem europeia. No final do século XVIII, portanto, as exportações da Bahia para a África Centro-Ocidental era principalmente um negócio de reexportações.

Vale aqui uma comparação com o Rio de Janeiro: os mapas da capital do Brasil são visivelmente incompletos, pois geralmente constam apenas as exportações de produtos da terra. ${ }^{51}$ Ademais, apenas os volumes foram discriminados por portos, enquanto que os valores foram agregados em cada classe de mercadoria. Foi necessário, portanto, calcular o valor de cada conjunto de mercadorias exportadas para Angola para então somar o total. ${ }^{52}$ Assoma-se a isto mais uma incongruência, como já havia notado J. Miller, muitos dos alimentos registrados como exportação no Rio de Janeiro eram, na verdade, utilizados para alimentar a escravaria no retorno e por isto não constavam sua entrada na Alfândega de Luanda. ${ }^{53}$

\footnotetext{
${ }^{49}$ E nos mapas da Bahia estão registradas remessas de moeda para o Rio Grande que permitiram saldar com folga os déficits em transações com mercadorias.

${ }^{50}$ Mais curiosa ainda é a balança de comércio com Costa da Mina na qual, apesar do decantado papel do tabaco, os défictis são ainda mais absurdos. Na soma dos anos entre 1798 e 1807, o déficit foi de mais de 3.030 contos de réis. Na falta de outra explicação, tudo indica que os mercadores da Bahia remetiam muita moeda para a Costa da Mina. Os mapas, portanto, comprovam a tese de Gustavo Acioli de que uma parte expressiva dos escravos era comprada com ouro naquela zona (cf. Negócio da Costa da Mina..., op. cit.). Assim as pequenas importações de ouro registradas nos mapas devem ser apenas o resto dessas negociações.

${ }^{51}$ A única exceção foi o ano de 1798, quando foi incluída a exportação de vinho e vinagre, presume-se de origem portuguesa.

${ }^{52}$ Por exemplo, em 1804 consta o volume do açúcar exportado para Angola (1.052 arrobas), o volume total exportado para todas as praças (442.863 arrobas) e o seu valor total (1.160.813.040 réis). Tive então de deduzir o preço médio da cada produto, no caso do açúcar (2.621 réis), para então calcular o valor exportado para Angola (2.757.456 réis em açúcar).

${ }^{53}$ MILLER, Joseph. Imports at Luanda..., op. cit.
} 
Maximiliano Mac MENZ. As "geometrias" do tráfico.

Tabela 8: exportações de produtos da terra do Rio de Janeiro para Angola (réis)

\begin{tabular}{|c|c|c|c|c|}
\hline \multirow{2}{*}{ Ano } & $\mathbf{a}$ & $\mathbf{b}$ & $\mathbf{c}$ & $\mathbf{d}$ \\
\cline { 2 - 5 } & prod. da terra & jeribitas & navios & $\begin{array}{c}\text { carga por navio } \\
\mathbf{a} / \mathbf{c}\end{array}$ \\
\hline 1796 & 82.250 .753 & 63.380 .338 & 14 & 5.875 .054 \\
\hline 1798 & 65.339 .641 & 35.086 .063 & 7 & 9.334 .234 \\
\hline 1803 & 86.680 .144 & 67.298 .453 & 13 & 6.667 .703 \\
\hline 1804 & 161.312 .128 & 132.643 .174 & 18 & 8.961 .785 \\
\hline
\end{tabular}

Fontes: 1796, AHU, RJ, cx. 160, doc. 12025; 1798, AHU, RJ, cx. 171, doc. 12689; 1803, AHU, RJ, cx. 225, doc. 15540; 1804, BNRJ, I-32, 14, 5, nº 13.

A tabela 8 revela a importância em termos absolutos dos gêneros da terra para o tráfico operado a partir do Rio de Janeiro. É possível, porém, fazer uma estimativa bastante grosseira do peso relativo dos produtos da terra nas carregações da capital do Brasil: cruzando as exportações baianas para Angola e Benguela com o número de navios negreiros que partiram do porto nordestino, chega-se a uma carga média de 12.554.181 réis. Supondo que no Rio de Janeiro a carga média das embarcações era igual a da Bahia, é possível estimar que os produtos da terra (coluna d) eram em torno de 47 e $71 \%$ das exportações da capital do Brasil para o porto africano. Esta maior participação de produtos americanos no comércio entre o Rio de Janeiro e Angola reflete o papel desempenhado pela cachaça, representando sempre mais da metade das mercadorias da terra e em torno de 36 e 59\% do total das exportações do Rio para Luanda.

Sobre o papel dos fretes no carregamento de escravos para o Rio de Janeiro não é possível concluir nada com os dados bastante defeituosos que possuo. Não obstante, existem indícios já apontados que também o Rio de Janeiro acumulava déficits com Angola (tabela 5); estes déficits representam os escravos importados pelo Rio, cobertos pelas exportações portuguesas e pagos, portanto, com letras ou moeda na capital do Brasil. Como também para o Rio de Janeiro as rotas triangulares eram incomuns, é provável que uma parte dos escravos tenha sido carregada em frete para este porto.

As vantagens comparativas dos mercadores do Brasil estavam, portanto, no fornecimento de aguardente, principalmente do Rio de Janeiro, e na posse de uma marinha mercante competitiva. No que diz respeito ao fornecimento de manufaturados, competiam apenas na margem, aproveitando-se das oscilações da navegação metropolitana. Acredito que isto explica particularmente porque no ano de 1796 as exportações de produtos da terra do Rio de Janeiro foram relativamente 
baixas, pois neste mesmo ano Lisboa remeteu cargas insignificantes para Angola (ver tabelas 1 e 8).

\section{Conclusão}

As estimativas e os cálculos apresentados aqui não deixam margem a dúvidas: entre 1796 e 1807 Portugal forneceu a maior parte das mercadorias utilizadas para o resgate de cativos em Angola. O financiamento do tráfico de escravos, apesar de ter um pequeno peso relativo no conjunto do comércio português no Atlântico, garantia saldos expressivos que compensavam o negócio com o Brasil, especialmente no norte-nordeste, onde as exportações de produtos tropicais ordinariamente superavam as importações de mercadorias europeias. Deste modo, os portos metropolitanos restringiam a remessa de moeda para a América, problema que não era menor na era do mercantilismo, não por causa de uma obsessão irracional por ouro e prata, mas porque os metais preciosos serviam como capital de giro e eram utilizados no comércio asiático. ${ }^{54}$ Circuito fechado, o fluxo de moedas era parcialmente controlado pelos agentes metropolitanos graças ao tráfico em Angola; a moeda garantia o acesso à rota do Cabo e aos têxteis da Índia; estes, por sua vez, eram fundamentais para o tráfico em Angola.

Configura-se assim um tipo de hierarquia espacial baseada no crédito, em mercadorias e rotas mercantis e organizada politicamente pelo exclusivo metropolitano. É notável que em Portugal o tráfico não tenha, a primeira vista, influenciado as atividades de transformação na economia metropolitana, apesar do surto industrial que se verificou no período. Angola era irrelevante enquanto mercado para as manufaturas portuguesas, não produzindo o tipo de externalidades positivas que o tráfico de escravos provocou na economia inglesa do século XVIII. ${ }^{55}$ Há um ponto, porém, que merece ser ainda mais investigado: a relação entre o tráfico triangular no sentido estrito e o comércio e transporte de algodão nas capitanias do Maranhão, Grão-Pará e Pernambuco, principais destinos das embarcações que faziam esta rota. É possível, portanto, que exista um polo de

\footnotetext{
${ }^{54}$ Cf. WILSON, Charles. 'Mercantilism': some vicissitudes of an Idea. The Economic History Review, New Series, v. 10, n. 2, 1957.

${ }^{55}$ Cf. INIKORI, Joseph. African and the Industrial Revolution in England: A study in international trade and economic development. Cambridge: Cambridge University Press, 2002. Ver ainda: DARITY Jr., Wiliam. British Industries and the West Indies Plantations. In: INIKORI, Joseph; ENGERMAN, Stanley (Eds.). The Atlantic Slave Trade: Effects on Economies, Societies, and Peoples in Africa, the Americas, and Europe. Durham/London: Duke University Press, 1992, p. 247279. BLACKBURN, Robin. The Making of New World Slavery. London/New York: Verso, 1997.
} 
contato entre escravidão e industrialização no sistema Atlântico português a ser desvendado.

Neste sentido, concordo com Fernando Novais que o exclusivo metropolitano era uma das "peças fundamentais" do sistema, mas ao invés de enfocar o problema dos sobre-lucros, considero que era pelo exclusivo que Portugal conseguia certo controle sobre os fluxos mercantis do Atlântico português durante o século XVIII. ${ }^{56}$

Ademais, este estudo confirma que a conjuntura do Atlântico Português durante o final do século XVIII e os primeiros anos do século XIX foi positiva. Até aí nenhuma novidade, pois desde o final dos anos 70 autores das mais variadas matizes historiográficas vêm reiterando esta ideia. Mas, em minha opinião, os números aqui apresentados obrigam a repensar a proposição de que esta expansão gerou uma inversão de polos entre metrópole e colônia, pois a participação metropolitana no tráfico é visivelmente positiva durante o período. Além disso, como foi sugerido, todo o debate sobre déficits e superávits precisa ser revisto à luz da balança de comércio entre Portugal, Brasil e Angola. ${ }^{57}$

O controle dos mercadores "brasílicos" sobre o tráfico de escravos em Angola só pôde ocorrer de modo duradouro depois de 1808. Com o fim do exclusivo metropolitano os homens de negócio das praças do Brasil acessaram livremente, e a preços competitivos, as cargas de manufaturados europeus e asiáticos. Também a vinda da família Real ao Brasil foi decisiva, pois provocou um curto no circuito típico dos homens de negócio; com a corte no Rio de Janeiro era possível acessar localmente os privilégios e os aparelhos do Estado que favoreciam aos grandes negociantes ${ }^{58}$ No que diz respeito ao tráfico, portanto, o ano de1808 deve ser visto pela descontinuidade.

Finalmente, é possível reconhecer algum fundamento na tese do domínio do "capital mercantil residente" sobre o tráfico. No entanto, o conceito é claramente inapropriado pelas razões já apontadas; é necessário, portanto, descolar a residência provisória das pessoas do fluxo muito mais sinuoso do capital mercantil.

No final do século XVIII, na Bahia e em Pernambuco os homens de negócio que residiam na colônia controlavam de modo esmagador o tráfico na Costa da Mina, e é possível que os mercadores do Rio de Janeiro fizessem a maior parte do tráfico de Benguela com capitais próprios. Os comerciantes coloniais também eram responsáveis pela revenda dos cativos nos mercados americanos do interior,

\footnotetext{
${ }^{56}$ Cf. NOVAIS, Fernando. Portugal e o Brasil na Crise do Antigo Sistema Colonial. op. cit., p. 72.

${ }^{57}$ Estou pensando aqui no célebre debate entre Fernando Novais, Valentim Alexandre, Jobson Arruda e Jorge Pedreira.

${ }^{58}$ Devo esta ideia a um comentário feito pelo Prof. Jorge Pedreira em sala de aula.
} 
como Minas Gerais, ou então no Rio da Prata; negócios que seguramente movimentavam grandes capitais. ${ }^{59}$

Em todo o caso, deve-se ainda quantificar de modo mais preciso o comércio direto entre Brasil e África para chegarmos a alguma grandeza de valor a respeito da participação relativa dos mercadores "brasílicos" no tráfico. A tese também deve ser testada no tempo e no espaço, posto que a organização financeira do resgate parece ter variado nas diferentes conjunturas e feitorias africanas. $\mathrm{Ou}$ seja, mais do que repetir o consenso, temos de problematizá-lo.

\section{APÊNDICE}

a) O terceiro método de calcular a participação relativa da metrópole no fornecimento de mercadorias para o resgate é pelo número de embarcações que deram entrada no porto de Luanda. O primeiro passo foi calcular a carga média das embarcações que saíram da Bahia para Angola e Benguela durante os nove anos para os quais encontrei os registros de exportação e de embarcações (12.554.181 réis); em seguida, extrapolei estes números para todas as naves que deram entrada em Luanda com origem nos portos do Brasil. Seguindo o mesmo procedimento para Portugal, calculei a carga média das embarcações metropolitanas dividindo as exportações portuguesas pelo total de embarcações que tiraram passaporte (72) para os diferentes portos de Angola (72.861.145 réis). Em seguida, multipliquei o número de embarcações que efetivamente entraram no porto de Luanda, segundo os dados do Database (53), pela carga média. Este cálculo, portanto, evita o problema relativo à indefinição dos portos onde as mercadorias eram vendidas realmente.

Vale dizer, porém, que o resultado superestima as cargas de origem brasileira, tendo em vista que as exportações para Benguela estão separadas nas Balanças de Comércio portuguesas, enquanto que nos dados da Bahia estas exportações foram somadas às exportações que tinham Luanda como destino.

\footnotetext{
${ }^{59}$ VERGER, Pierre F. Fluxo e Refluxo do Tráfico de Escravos entre o Golfo de Benin e a Bahia de Todos os Santos: dos séculos XVII a XIX. Salvador: Corrupio, 1987, original de 1968, passim. LOPES, Gustavo Acioli. Negócio da Costa da Mina..., op. cit., passim. Sobre Benguela, ver MILLER, Joseph. Way of Death..., op. cit., p. 468-504. Sobre a revenda de escravos, além do próprio Miller, ver RIBEIRO, Alexandre Vieira. O tráfico atlâtico de escravos e a praça mercantil de Salvador. op. cit.
} 
Maximiliano Mac MENZ. As "geometrias" do tráfico.

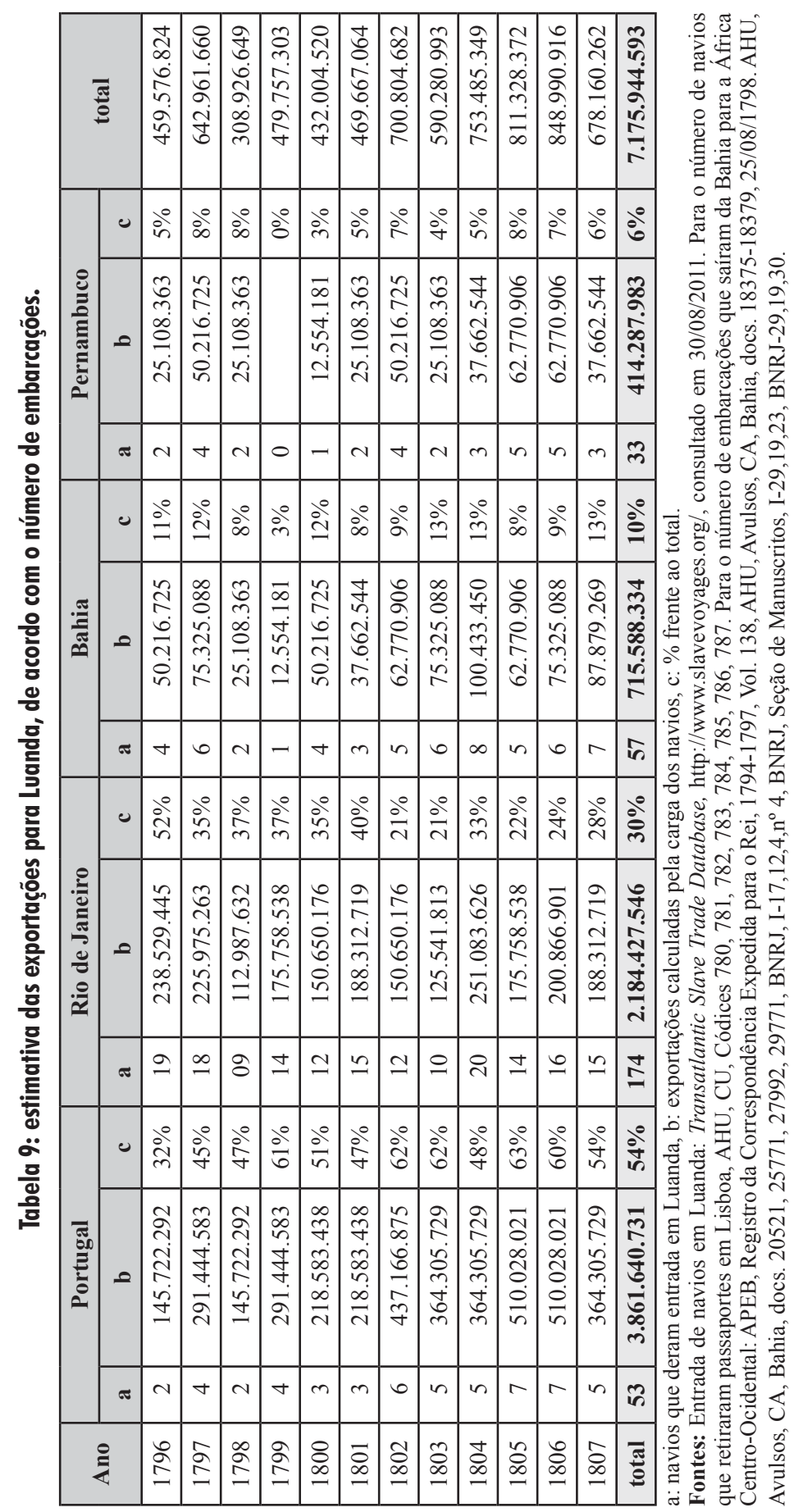

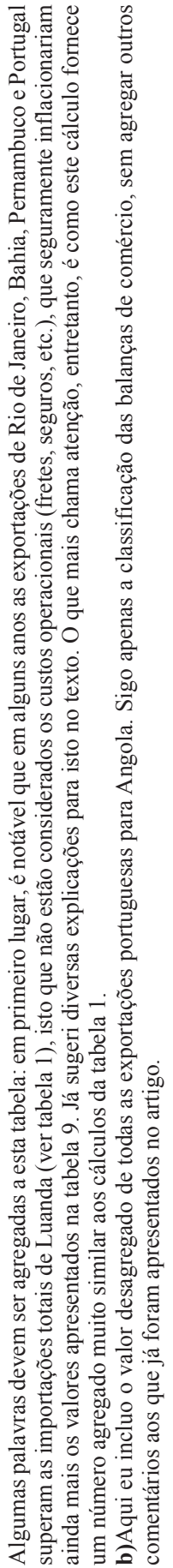


Maximiliano Mac MENZ. As "geometrias" do tráfico.

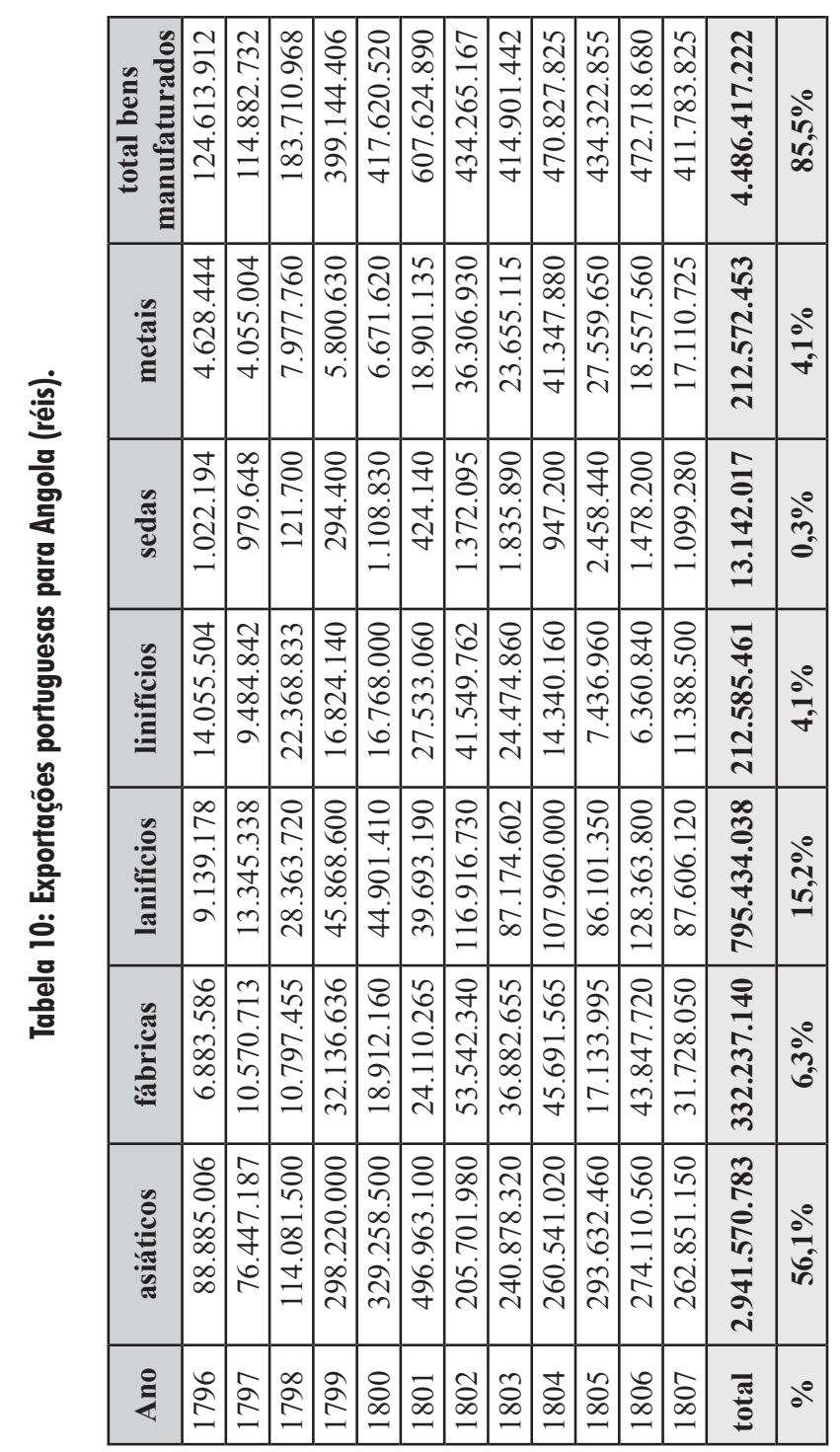




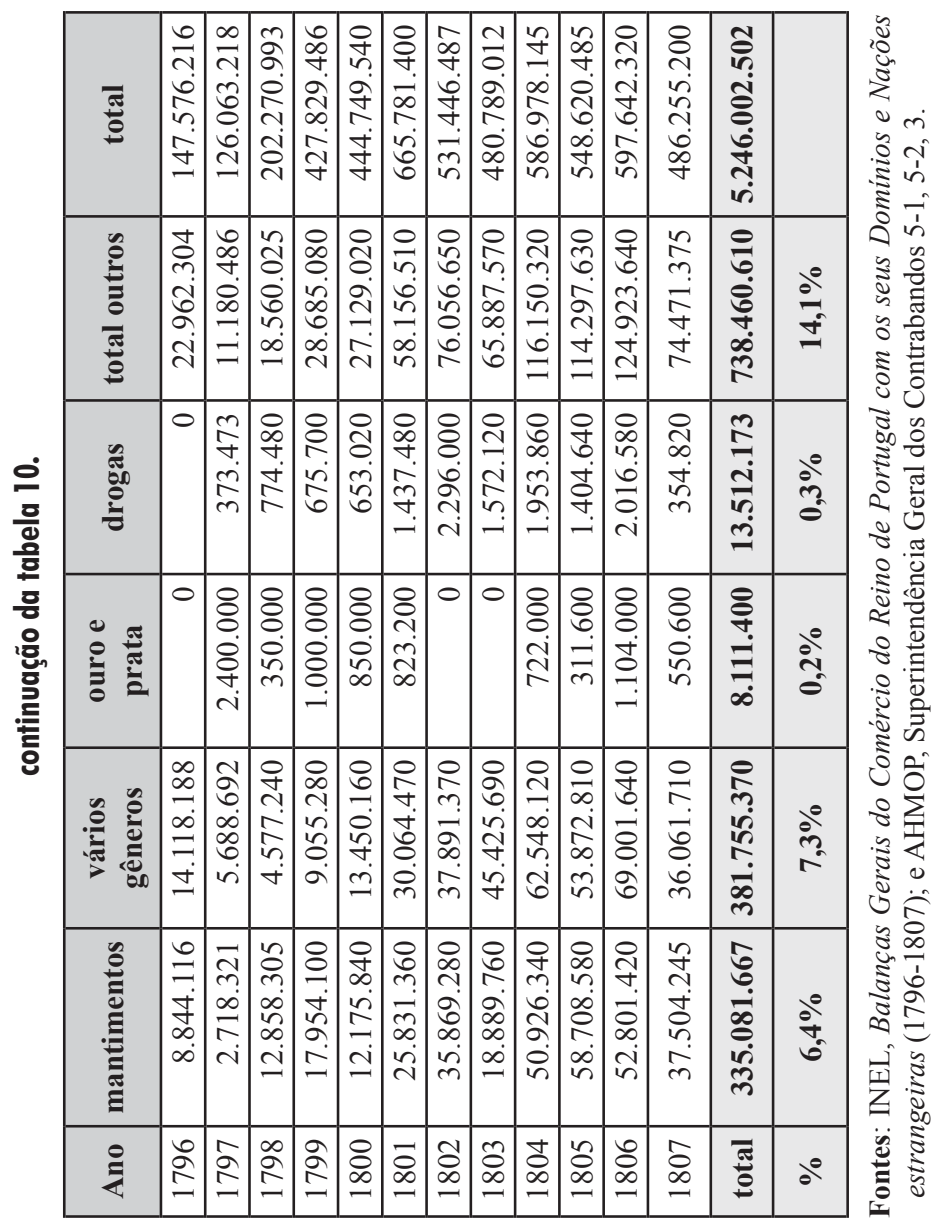

\section{Referências Bibliográficas}

ALENCASTRO, Luiz Felipe de. O Trato dos Viventes: formação do Brasil no Atlântico Sul. São Paulo: Companhia das Letras, 2000.

ALEXANDRE, Valentim. Os Sentidos do Império: Questão nacional e questão colonial na crise do Antigo Regime português. Porto: Edições Afrontamento, 1993.

. Um momento crucial do subdesenvolvimento português: efeitos económicos da perda do Império Brasileiro. Ler História, n. 7, 1986, p. 3-45.

ARRUDA, José Jobson de. O Brasil no Comércio Colonial. São Paulo: Ática, 1980. 
BLACKBURN, Robin. The Making of New World Slavery. London/New York: Verso, 1997.

COSTA, Leonor. O Transporte no Atlântico e a Companhia Geral do Comércio do Brasil, 1580-1663. Lisboa: CNCDP, 2002.

CURTO, José. Álcool e Escravos. O comércio luso-brasileiro do álcool em Mpinda, Luanda e Benguela durante o tráfico atlântico de escravos (c. 1480-1830) e o seu impacto nas sociedades da África Central e Ocidental. Lisboa: Vulgata, 2002.

DARITY Jr., Wiliam. British Industries and the West Indies Plantations. In: INIKORI, Joseph; ENGERMAN, Stanley (Eds.). The Atlantic Slave Trade: Effects on Economies, Societies, and Peoples in Africa, the Americas, and Europe. Durham/ London: Duke University Press, 1992, p. 247-279.

DAVIS, Ralph. The Rise of the English Shipping Industry. London: MacMillan, 1962.

FERREIRA, Roquinaldo. Transforming Atlantic Slaving: Trade, warfare and territorial control in Angola, 1650-1800. PhD Dissertation, Los Angeles: University of California, 2003.

FLORENTINO, Manolo. Em Costas Negras. São Paulo: Companhia das Letras, 1997.

. Tráfico Atlântico, mercado colonial e famílias escravas no Rio de Janeiro, Brasil, c. 1790-ca. 1830. História Questões \& Debates, n. 51, 2009, p. 69-119.

FRUTUOSO, E.; GUINOTE, P.; LOPES, A. O Movimento do Porto de Lisboa e o Comércio Luso-Brasileiro (1769-1836). Lisboa: CNCDP, 2001.

INIKORI, Joseph. African and the Industrial Revolution in England: A study in international trade and economic development. Cambridge: Cambridge University Press, 2002.

KLEIN, Herbert. The portuguese slave trade from Angola in 18th century. In: Idem. The Middle Passage. Princeton: Princeton University Press, 1978, p. 23-50.

LOPES, Gustavo Acioli; MENZ, Maximiliano M. Resgate e Mercadorias: Uma análise comparada do tráfico luso-brasileiro em Angola e na Costa da Mina (século XVIII). Afro-Ásia, n. 37, 2008.

LOPES, Gustavo Acioli. Negócio da Costa da Mina e comércio atlântico - tabaco, açúcar, ouro e tráfico de escravos: Pernambuco (1654-1760). Tese de Doutorado, São Paulo, USP, 2008.

MACEDO, Jorge. Problemas de História da Indústria Portuguesa no século XVIII. Lisboa: Querco, 1982, $2^{\mathrm{a}}$ ed.

MILLER, Joseph. Way of Death: Merchant Capitalism and the Angolan Slave Trade, 1730-1830. Winscosin: The Universisty of Winscosin Press, 1988.

. Imports at Luanda, Angola 1785-1823. In: PASCH, G.; JONES, A. Figuring African Trade. Berlin: Reimer, 1986.

Slave Prices in the Portuguese Southern Atlantic, 1600-1830. In: LOVEJOY, Paul (Ed.). Africans in Bondage. Studies in slavery and slave trade. 
Maximiliano Mac MENZ. As "geometrias" do tráfico.

Winscosin: African Studies Program; University of Winscosin, 1986.

MINCHINTON, Walter E. The Triangular Trade Revisited. In: GEMERY, Henry A.; HOGENDORN, Jan S. (Eds.). The Uncommon Market. Essays in the Economic History of Atlantic Slave Trade. Nova York: Academic Press, 1979.

MENZ, Maximiliano M. A Companhia de Pernambuco e o funcionamento do tráfico de escravos em Angola. (artigo inédito), 2011.

NOVAIS, Fernando. Portugal e Brasil na Crise do Antigo Sistema Colonial. São Paulo: Hucitec, 1995, $6^{\text {a }}$ ed.

PALACIOS, Guillermo. Cultivadores Libres, Estado y Crisis de la Esclavitud en Brasil en la Época de la Revolución Industrial. Ciudad de Mexico: FCE, 1998.

PEDREIRA, Jorge. Brasil, fronteira de Portugal. Negócio, emigração e mobilidade social (séculos XVII e XVIII). In: CUNHA, Mafalda (Coord.). Do Brasil à Metrópole, efeitos sociais (séculos XVII-XVIII). Anais da Universidade de Évora, n. 8 e $9,1998 / 1999$, p. 47-72.

Estrutura Industrial e Mercado Colonial Portugal e Brasil (1780-1830). Lisboa: Difel, 1994.

PESAVENTO, Fábio. Um pouco antes da Corte: a economia do Rio de Janeiro na segunda metade do setecentos. Tese de Doutorado, Niterói, UFF, 2009.

RIBEIRO, Alexandre Vieira. O tráfico atlântico de escravos e a praça mercantil de Salvador. Dissertação de Mestrado, Rio de Janeiro, UFRJ, 2005.

SAMPAIO, Antonio C. Na Encruzilhada do Império. Hierarquias sociais e conjunturas econômicas no Rio de Janeiro. Rio de Janeiro: Arquivo Nacional, 2001.

SANTOS, Cocino. O Rio de Janeiro e a Conjuntura Atlântica. Rio de Janeiro: Expressão e Cultura, 1993.

SILVA, Daniel Domingues da. The Atlantic Slave Trade to Maranhão, 1680-1846. Volume, Routes and Organization. Slavery \& Abolition. v. 29, n. 4, 2008, p. 477-501.

VERGER, Pierre F. Fluxo e Refluxo do Tráfico de Escravos entre o Golfo de Benin e a Bahia de Todos os Santos: dos séculos XVII a XIX. Salvador: Corrupio, 1987; original de 1968.

WILSON, Charles. 'Mercantilism': some vicissitudes of an Idea. The Economic History Review, New Series, v. 10, n. 2, 1957.

\section{Acervos documentais utilizados}

Arquivo Histórico do Ministério de Obras Públicas (AHMOP), Superintendência Geral dos Contrabandos.

Arquivo Histórico Ultramarino (AHU), Avulsos, Angola.

AHU, Avulsos, Bahia.

AHU, Avulsos, Castro de Almeida, Bahia.

AHU, Avulsos, Rio de Janeiro. 
AHU, Conselho Ultramarino, Códices (passaportes).

Arquivos Nacionais Torre do Tombo (ANTT), Companhia Geral de Pernambuco e Paraíba (CGPP), Junta de Lisboa.

Arquivo Público do Estado da Bahia (APEB), Registro da Correspondência Expedida para o Rei.

Biblioteca Nacional do Rio de Janeiro (BNRJ), Seção de Manuscritos.

Instituto de Estudos Brasileiros (IEB), Coleção Lamego.

Instituto Nacional de Estatística (INEL), Balanças Gerais do Comércio do Reino de Portugal com os seus Domínios e Nações estrangeiras (1796-1807).

\section{Acervos on line:}

The Transatlantic Slave Trade Database (TSTD). http://www.slavevoyages.org/tast/ index.faces

Ius Lusitaniae - Fontes Históricas do Direito Português. http://iuslusitaniae.fcsh. unl.pt/

Recebido: 09/08/2010 - Aprovado: 14/10/2011 